\title{
Geology and Assessment of Undiscovered Oil and Gas Resources of the Jan Mayen Microcontinent Province, 2008
}

Chapter L of

The 2008 Circum-Arctic Resource Appraisal

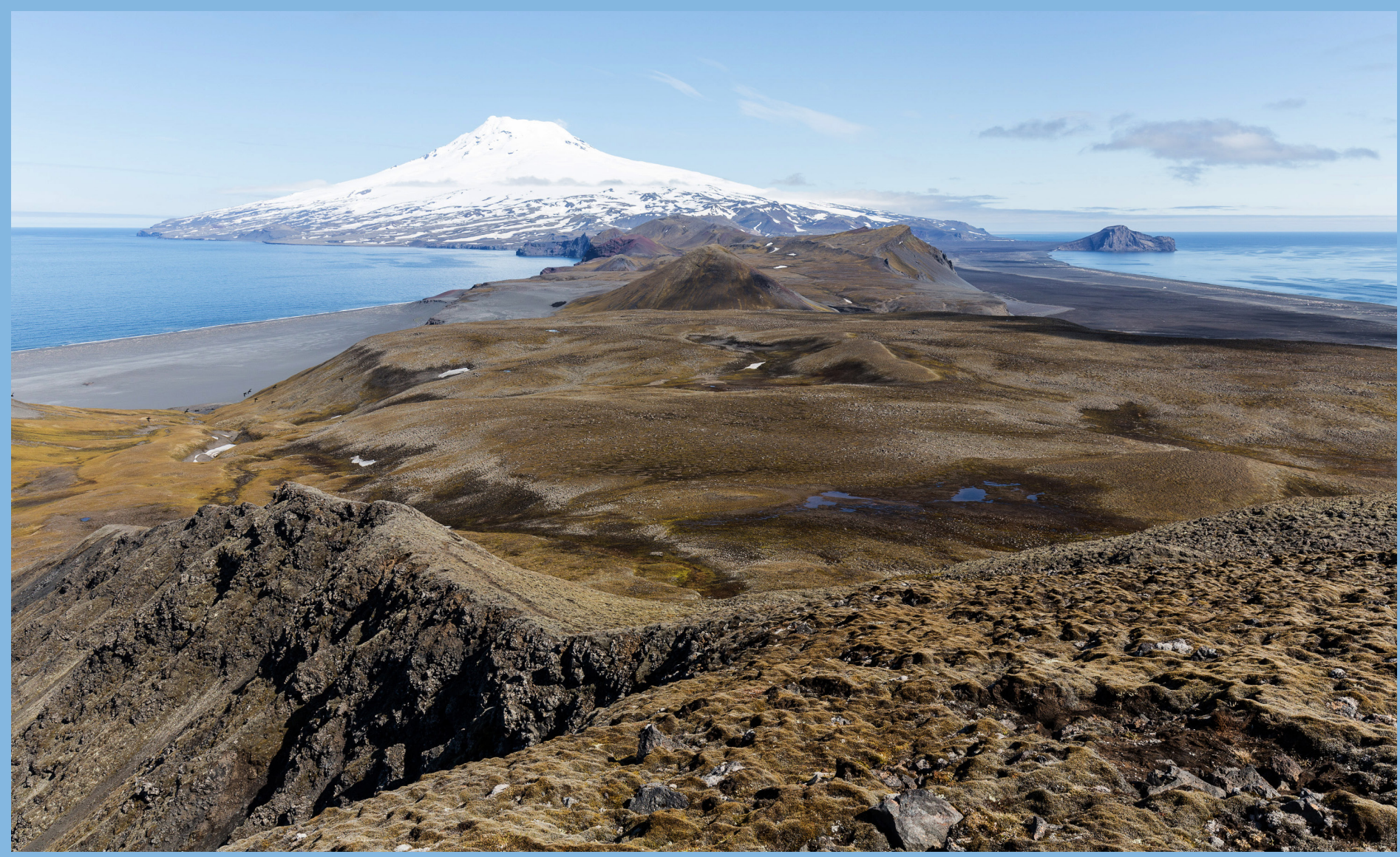

Professional Paper 1824

U.S. Department of the Interior

U.S. Geological Survey 
COVER

Photo looking north from Antarcticberget toward Beerenberg volcano on Jan Mayen Island in the North Atlantic 0cean. The island marks the northernmost part of the Jan Mayen Microcontinent, a submerged fragment of continental crust that was rifted away from eastern Greenland about 20 million years ago. The island consists of young basaltic rocks erupted from the Jan Mayen Fracture Zone, which bounds the microcontinent on the north. Photo copyright Rolf Stange, 2016, https://www.spitsbergen-svalbard.com 


\section{Geology and Assessment of Undiscovered Oil and Gas Resources of the Jan Mayen Microcontinent Province, 2008}

By Thomas E. Moore and Janet K. Pitman

Chapter $\mathrm{L}$ of

The 2008 Circum-Arctic Resource Appraisal

Edited by T.E. Moore and D.L. Gautier

Professional Paper 1824 


\title{
U.S. Department of the Interior RYAN K. ZINKE, Secretary
}

\section{U.S. Geological Survey William H. Werkheiser, Deputy Director exercising the authority of the Director}

\author{
U.S. Geological Survey, Reston, Virginia: 2018
}

For more information on the USGS — the Federal source for science about the Earth, its natural and living resources, natural hazards, and the environment-visit https://www.usgs.gov or call 1-888-ASK-USGS.

For an overview of USGS information products, including maps, imagery, and publications, visit https://store.usgs.gov.

Any use of trade, firm, or product names is for descriptive purposes only and does not imply endorsement by the U.S. Government.

Although this information product, for the most part, is in the public domain, it also may contain copyrighted materials as noted in the text. Permission to reproduce copyrighted items must be secured from the copyright owner.

Suggested citation:

Moore, T.E., and Pitman, J.K., 2018, Geology and assessment of undiscovered oil and gas resources of the Jan Mayen Microcontinent Province, 2008, chap. L of Moore, T.E., and Gautier, D.L., eds., The 2008 Circum-Arctic Resource Appraisal: U.S. Geological Survey Professional Paper 1824, 18 p., https://doi.org/10.3133/pp1824L.

ISSN 2330-7102 (online 


\section{The 2008 Circum-Arctic Resource Appraisal}

\section{Chapters}

A. Introduction to the 2008 Circum-Arctic Resource Appraisal (CARA) Professional Paper By Donald L. Gautier and Thomas E. Moore

B. Methodology for Assessment of Undiscovered Oil and Gas Resources for the 2008 Circum-Arctic Resource Appraisal

By Ronald R. Charpentier

\section{North America}

C. Geology and Assessment of Undiscovered Oil and Gas Resources of the Chukchi Borderland Province, 2008

By Kenneth J. Bird and David W. Houseknecht

D. Geology and Assessment of Undiscovered Oil and Gas Resources of the Hope Basin

Province, 2008

By Kenneth J. Bird, David W. Houseknecht, and Janet K. Pitman

E. Geology and Assessment of Undiscovered Oil and Gas Resources of the Arctic Alaska Petroleum Province, 2008

By David W. Houseknecht, Kenneth J. Bird, and Christopher P. Garrity

F. Geology and Assessment of Undiscovered Oil and Gas Resources of the Yukon Flats Basin Province, 2008

By Kenneth J. Bird and Richard G. Stanley

G. Geology and Assessment of Undiscovered Oil and Gas Resources of the Northwest Canada Interior Basins Province, Arctic Canada, 2008

By Marilyn E. Tennyson and Janet K. Pitman

H. Geology and Assessment of Undiscovered Oil and Gas Resources of the Franklinian Shelf Province, Arctic Canada and North Greenland, 2008

By Marilyn E. Tennyson and Janet K. Pitman

I. Geology and Assessment of Undiscovered Oil and Gas Resources of the Sverdrup Basin Province, Arctic Canada, 2008

By Marilyn E. Tennyson and Janet K. Pitman

\section{Greenland}

J. Geology and Assessment of Undiscovered Oil and Gas Resources of the West GreenlandEast Canada Province, 2008

By Christopher J. Schenk 
K. Geology and Assessment of Undiscovered Oil and Gas Resources of the East Greenland Rift Basins Province, 2008

By Donald L. Gautier

\section{North Atlantic Ocean}

L. Geology and Assessment of Undiscovered Oil and Gas Resources of the Jan Mayen Microcontinent Province, 2008

By Thomas E. Moore and Janet K. Pitman

\section{Eurasia}

M. Geology and Assessment of Undiscovered Oil and Gas Resources of the Mezen' Basin Province, 2008

By Timothy R. Klett and Janet K. Pitman

N. Geology and Assessment of Undiscovered Oil and Gas Resources of the Timan-Pechora Basin Province, Russia, 2008

By Christopher J. Schenk

0. Geology and Assessment of Undiscovered Oil and Gas Resources of the East Barents Basins Province and the Novaya Zemlya Basins and Admiralty Arch Province

By Timothy R. Klett

P. Geology and Assessment of Undiscovered Oil and Gas Resources of the North Kara Basins and Platforms Province, 2008

By Timothy R. Klett and Janet K. Pitman

0. Geology and Assessment of Undiscovered Oil and Gas Resources of the Northern West Siberian Mesozoic Composite Total Petroleum System of the West Siberian Basin Province, Russia, 2008

By Christopher J. Schenk

R. Geology and Assessment of Undiscovered Oil and Gas Resources of the Yenisey-Khatanga Basin Province, 2008

By Timothy R. Klett and Janet K. Pitman

S. Geology and Assessment of Undiscovered Oil and Gas Resources of the Northwest Laptev Sea Shelf Province, 2008

By Timothy R. Klett and Janet K. Pitman

T. Geology and Assessment of Undiscovered Oil and Gas Resources of the Lena-Anabar Basin Province, 2008

By Timothy R. Klett and Janet K. Pitman 
U. Geology and Assessment of Undiscovered Oil and Gas Resources of the Tunguska Basin Province, 2008

By Christopher J. Wandrey and Timothy R. Klett

V. Geology and Assessment of Undiscovered Oil and Gas Resources of the Lena-Vilyui Basin Province, 2008

By Timothy R. Klett and Janet K. Pitman

W. Geology and Assessment of Undiscovered Oil and Gas Resources of the Laptev Sea Shelf Province, 2008

By Timothy R. Klett and Janet K. Pitman

X. Geology and Assessment of Undiscovered Oil and Gas Resources of the Zyryanka Basin Province, 2008

By Timothy R. Klett and Janet K. Pitman

Y. Geology and Assessment of Undiscovered Oil and Gas Resources of the East Siberian Sea Basin Province, 2008

By Kenneth J. Bird, David W. Houseknecht, and Janet K. Pitman

Z. Geology and Assessment of Undiscovered Oil and Gas Resources of the Vilkitskii Basin Province, 2008

By Kenneth J. Bird, David W. Houseknecht, and Janet K. Pitman

AA. Geology and Assessment of Undiscovered Oil and Gas Resources of the Long Strait Province, Russian High Arctic, 2008

By Kenneth J. Bird, David W. Houseknecht, and Janet K. Pitman

\section{Arctic Ocean}

BB. Geology and Assessment of Undiscovered Oil and Gas Resources of the Amerasia Basin Petroleum Province, 2008

By David W. Houseknecht, Kenneth J. Bird, and Christopher P. Garrity

CC. Geology and Assessment of Undiscovered Oil and Gas Resources of the LomonosovMakarov Province, Central Arctic Ocean, 2008

By Thomas E. Moore, Kenneth J. Bird, and Janet K. Pitman

DD. Geology and Assessment of Undiscovered Oil and Gas Resources of the Eurasia Basin Province, Eastern Arctic Ocean, 2008

By Thomas E. Moore and Janet K. Pitman 


\section{Contents}

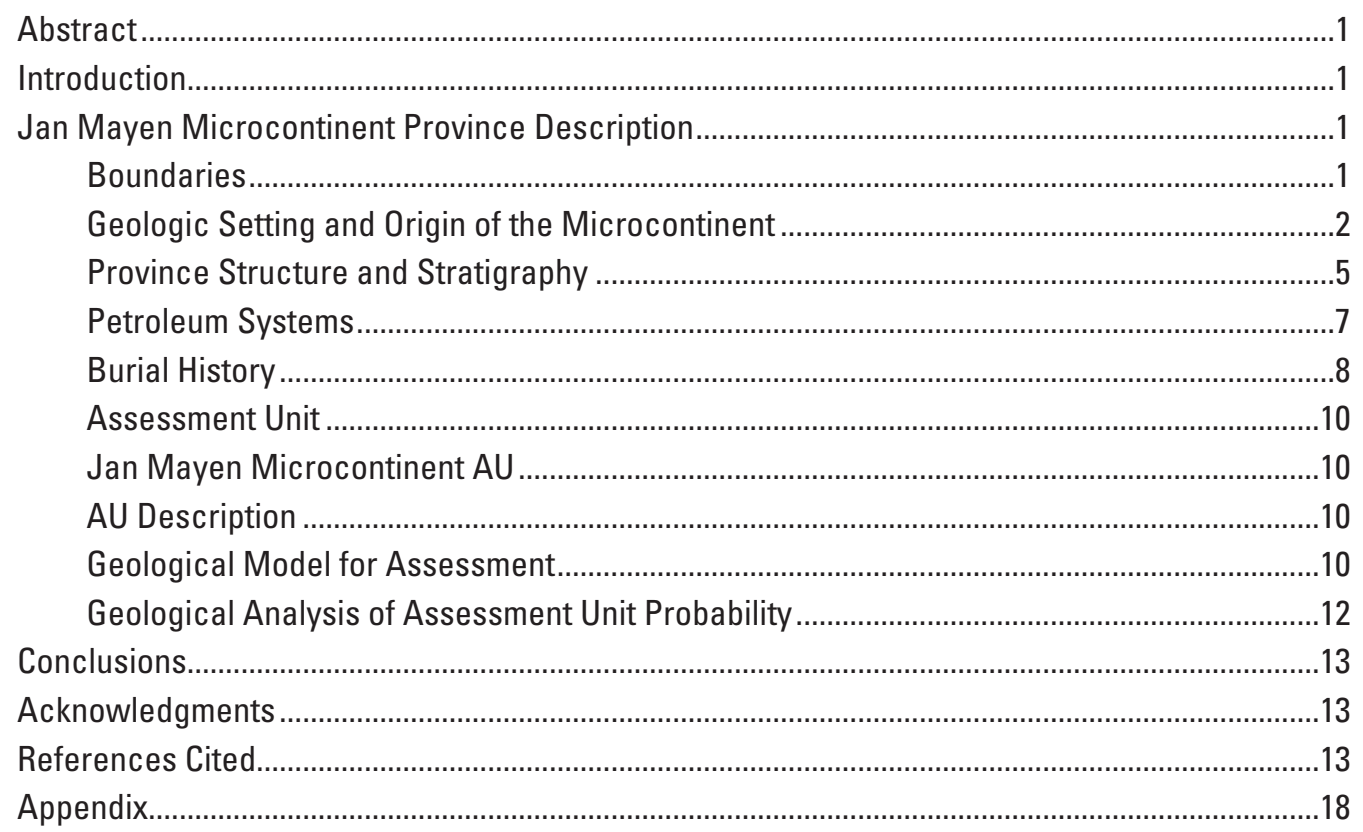

\section{Appendix}

[Available for download at https://doi.org/10.3133/pp1824L]

1. Input Data for the Jan Mayen Microcontinent Assessment Unit

\section{Figures}

1. Bathymetric map of the North Atlantic showing regional location of Jan Mayen Microcontinent and other features mentioned in text...

2. Plate tectonic origin of the Jan Mayen Microcontinent and the inferred track of the Iceland plume in the Cenozoic .....................................................................................................

3. Cross section across Jan Mayen Microcontinent and parts of the adjacent ocean basins ....5

4. Burial history model for pseudowell JMM located on west flank of Jan Mayen Ridge at $8.548^{\circ} \mathrm{W}, 69.273^{\circ} \mathrm{N}$.

5. Inferred lithostratigraphic column for the Jan Mayen Microcontinent, showing petroleumsystem elements and major tectonic events

\section{Table}

1. Stratigraphic model used to construct burial history model for pseudowell JMM. 


\title{
Chapter L
}

\section{Geology and Assessment of Undiscovered Oil and Gas Resources of the Jan Mayen Microcontinent Province, 2008}

\author{
By Thomas E. Moore and Janet K. Pitman
}

\section{Abstract}

The Jan Mayen Microcontinent encompasses a rectangular, mostly submarine fragment of continental crust that lies north of Iceland in the middle of the North Atlantic Ocean. These continental rocks were rifted away from the eastern margin of Greenland as a consequence of a westward jump of spreading centers from the now-extinct Aegir Ridge to the currently active Kolbeinsey Ridge in the Oligocene and early Miocene. The microcontinent is composed of the highstanding Jan Mayen Ridge and a series of smaller ridges that diminish southward in elevation and includes several deep basins that are underlain by strongly attenuated continental crust. The geology of this area is known principally from a loose collection of seismic reflection and refraction lines and several deep-sea scientific drill cores.

The Jan Mayen Microcontinent petroleum province encompasses the entire area of the microcontinent and was defined as a single assessment unit (AU). Although its geology is poorly known, the microcontinent is thought to consist of Late Paleozoic and Mesozoic rift basin stratigraphic sequences similar to those of the highly prospective Norwegian, North Sea, and Greenland continental margins. The prospectivity of the AU may be greatly diminished, however, by pervasive extensional deformation, basaltic magmatism, and exhumation that accompanied two periods of continental rifting and breakup in the Paleogene and early Neogene. The overall probability of at least one petroleum accumulation of $>50$ million barrels of oil equivalent was judged to be 5.6 percent. As a consequence of the low level of probability, a quantitative assessment of this AU was not conducted.

\section{Introduction}

The U.S. Geological Survey (USGS) in 2008 completed an appraisal of undiscovered, technically recoverable, conventional oil and gas resources north of the Arctic Circle. Results of that Circum-Arctic Resource Appraisal (CARA) include aggregate resource estimates for the entire Arctic region (Bird and others, 2008; Gautier and others, 2009, 2011a) and documentation of the geological framework and resource estimates for specific Arctic provinces (Bird and Houseknecht, 2011; Gautier and others, 2011b; Houseknecht and Bird, 2011; Houseknecht and others, 2012a,b; Klett and Pitman, 2011; Klett and others, 2011; Moore and Pitman, 2011; Moore and others, 2011; Schenk, 2011a,b; Sørensen and others, 2011). The procedures and methods used in conducting the CircumArctic Resource Appraisal are documented by Charpentier and Gautier (2011) and Charpentier (2017, this volume, chapter B) and the location and extent of the basins evaluated are delimited by Grantz and others $(2010,2011)$. The purpose of this chapter is to provide a synthesis of the petroleum geology of the Jan Mayen Microcontinent Province, to present the reasoning and input parameters used by the CARA assessment for its petroleum assessment, and to report the complete results of the resource assessment for the province.

\section{Jan Mayen Microcontinent Province Description}

\section{Boundaries}

The Jan Mayen Microcontinent Province of the 2008 Circum-Arctic Resource Appraisal (CARA) encompasses a rectangular region of mostly extended continental crust lying north of Iceland in the North Atlantic Ocean (fig. 1). The continental crust in this area is thought to compose a microcontinent (Nunns, 1983) that was rifted away from Greenland in the Oligocene and early Miocene and now hosts a petroleum province that is isolated from other petroleum provinces in the Circum-Arctic region. The province is bounded by oceanic crust on its eastern, northern, and western sides and is overlain by mafic volcanic rocks of the Iceland large igneous province (LIP) to the south. Except for Jan Mayen Island at its northern end, the province is submerged and lies at depths of $0 \mathrm{~m}$ to $2,500 \mathrm{~m}$.

The boundaries of the Jan Mayen Microcontinent petroleum province were adopted from Grantz and others $(2010,2011)$ and correspond to the continent-ocean boundaries of the Jan Mayen Microcontinent on the basis of oceanic magnetic anomaly patterns (Verhoef and others, 1996; Oakey and others, 1999), bathymetry (Jakobsson and others, 2004) 
and gravity data (Laxon and McAdoo, 1997). The eastern and western limits of the province are passive-margin continentocean boundaries whose locations were constrained principally by the extent of oceanic crust as identified by oceanic magnetic anomaly patterns. Although most workers generally agree on the position of these boundaries in the northern part of the microcontinent, there is more disagreement about the locations of the continent-ocean boundaries in its southern part. Grantz and others $(2010,2011)$ show a more westward location for the microcontinent than do some other interpretations (for example, Mjelde and others, 2008). Grantz and others $(2010,2011)$ defined the southern limit of the province as the inferred Faroe Fracture Zone along the aseismic Faroe-Iceland Ridge and its western extension beneath covering volcanic rocks along the northeastern margin of Iceland (Kimbell and others, 2005). Evidence of continental rocks at depth beneath eastern Iceland south of this boundary (Foulger, 2006; Paquett and others, 2006), however, suggests that the southern limit of the microcontinent could be more complicated beneath Iceland. Grantz and others $(2010,2011)$ show the northern boundary of the province as the West Jan Mayen Fracture Zone, a northwesttrending transform fault at the north end of Jan Mayen Island. Some workers have inferred that the microcontinent instead may be terminated at the western projection of the Central or Eastern Jan Mayen Fracture Zones (for example, Mjelde and others, 2008), transforms that Grantz and others $(2010,2011)$ interpreted as dying out at or in the eastern part of the microcontinent (fig. 1).

The province comprises a bathymetrically complex region having a north-south length of $\sim 600 \mathrm{~km}$, an east-west width of $\sim 200 \mathrm{~km}$ and covering $116,000 \mathrm{~km}^{2}$. The northern part of the province is dominated by the $400-\mathrm{km}$-long, north-trending, flat-topped Jan Mayen Ridge and adjacent 2,000-m-deep Jan Mayen Basin to the west. In its southern part, the Jan Mayen Ridge is obliquely transected by the northeast-trending Jan Mayen Trough. The southern part of the province is composed of several smaller ridges that become less distinct southward toward Iceland (the southern ridge complex of Gudlaugsson and others, 1988). Much of the southern part of the province lies at depths of 1,000 to $2,000 \mathrm{~m}$ and has crust that is thin and difficult to distinguish from oceanic crust on the basis of bathymetry, seismic reflection, and potential field data. (Mjelde and others, 2008)

\section{Geologic Setting and Origin of the Microcontinent}

The Jan Mayen Microcontinent was formed by a complex series of tectonic events during opening of the North Atlantic Ocean in the Paleogene and early Neogene. Although many details of the process that led to its development are still uncertain, the principal events are generally agreed upon (for example, Talwani and Eldholm, 1977; Lundin and Doré, 2002; Scott and others, 2005; Gaina and others, 2009) and are reviewed here (fig. 2).
Following an extensive episode of rifting in the Jurassic in the area of the future North Atlantic, breakup and seafloor spreading began in the region between Greenland and Norway at about $57 \mathrm{Ma}$ (Chron 24B, late Paleocene) (fig. 2A). The ridge axis for the spreading consisted of three primary ridge segments, from south to north, the Reykjanes, Aegir, and Mohns Ridges, which were separated by transform faults, the East Jan Mayen Land Fracture Zone on the north, and the inferred Iceland-Faroe Fracture Zone on the south. The former formed a left-step between the Aegir and Mohns ridge segments, whereas the latter formed a right-step between the Aegir and Reykjanes spreading ridges. As a consequence of rifting with this configuration, a salient was created in the continental margin of Greenland.

Sometime between $44 \mathrm{Ma}$ (Chron 20) and $20 \mathrm{Ma}$ (Chron 6) (fig. 2C), spreading on the Aegir Ridge shifted to a new ridge segment, the Kolbeinsey Ridge, which developed across the salient in the margin of Greenland (Mjelde and others, 2008). Spreading on the new ridge propagated northward into the salient and, by $20 \mathrm{Ma}$, rifted it away from the margin of Greenland. The rifted salient of Greenland now comprises the Jan Mayen Microcontinent. Because it was formed as a northward propagation of the Reykjanes Ridge into southeastern Greenland (Lundin and Doré, 2005), the rifting and spreading of the Kolbeinsey Ridge are thought to have caused the Jan Mayen Microcontinent to rotate counterclockwise. Whether the oceanic spreading at the Aegir Ridge jumped to, migrated to, or coexisted with formation of the Kolbeinsey Ridge is uncertain. The migration of spreading from the Aegir to the Kolbeinsey segments may have involved northward development of a series of transient transform faults (Scott and others, 2005) or an interplay of rotational spreading on the nascent Kolbeinsy and dying Aegir Ridges (Nunns, 1983; Lundin and Doré 2005; Gaina and others, 2009). Since $20 \mathrm{Ma}$, the Aegir Ridge has been extinct and the Kolbeinsey Ridge has been the active ridge segment for oceanic spreading in this part of the North Atlantic. As a result of the spreading, the Jan Mayen Microcontinent is now separated from Greenland by about $250 \mathrm{~km}$ of oceanic crust. The complex history of spreading in this area probably was caused by the change in the motion of Greenland relative to Eurasia at about $33 \mathrm{Ma}$ (Chron 13) (fig. 2B), which resulted in about $30^{\circ}$ counterclockwise change in the direction of spreading. This rotation is reflected in the oblique angle between the trends of the Oligocene and younger West Jan Mayen Fracture Zone and the Paleocene and Eocene East Jan Mayen Fracture Zone (Talwani and Eldholm, 1977).

In addition to the change of spreading directions, the Iceland large igneous province (LIP) may also have played a key role in the formation of the Jan Mayen Microcontinent. In most models, the LIP is thought to be the manifestation of a hot spot or mantle plume that migrated across Greenland from the west, arriving on the east coast of Greenland at about $35 \mathrm{Ma}$ (Lawver and Müller, 1994). This timing suggests that the plume may have encouraged the shift in spreading from the Aegir to the Kolbeinsey ridges in the Eocene to early Miocene. In addition, the LIP also is thought to have influenced rifting in the late 
$40^{\circ} \mathrm{W}$

$30^{\circ} \mathrm{W}$

$20^{\circ} \mathrm{W}$

$10^{\circ} \mathrm{W}$

$0^{\circ}$

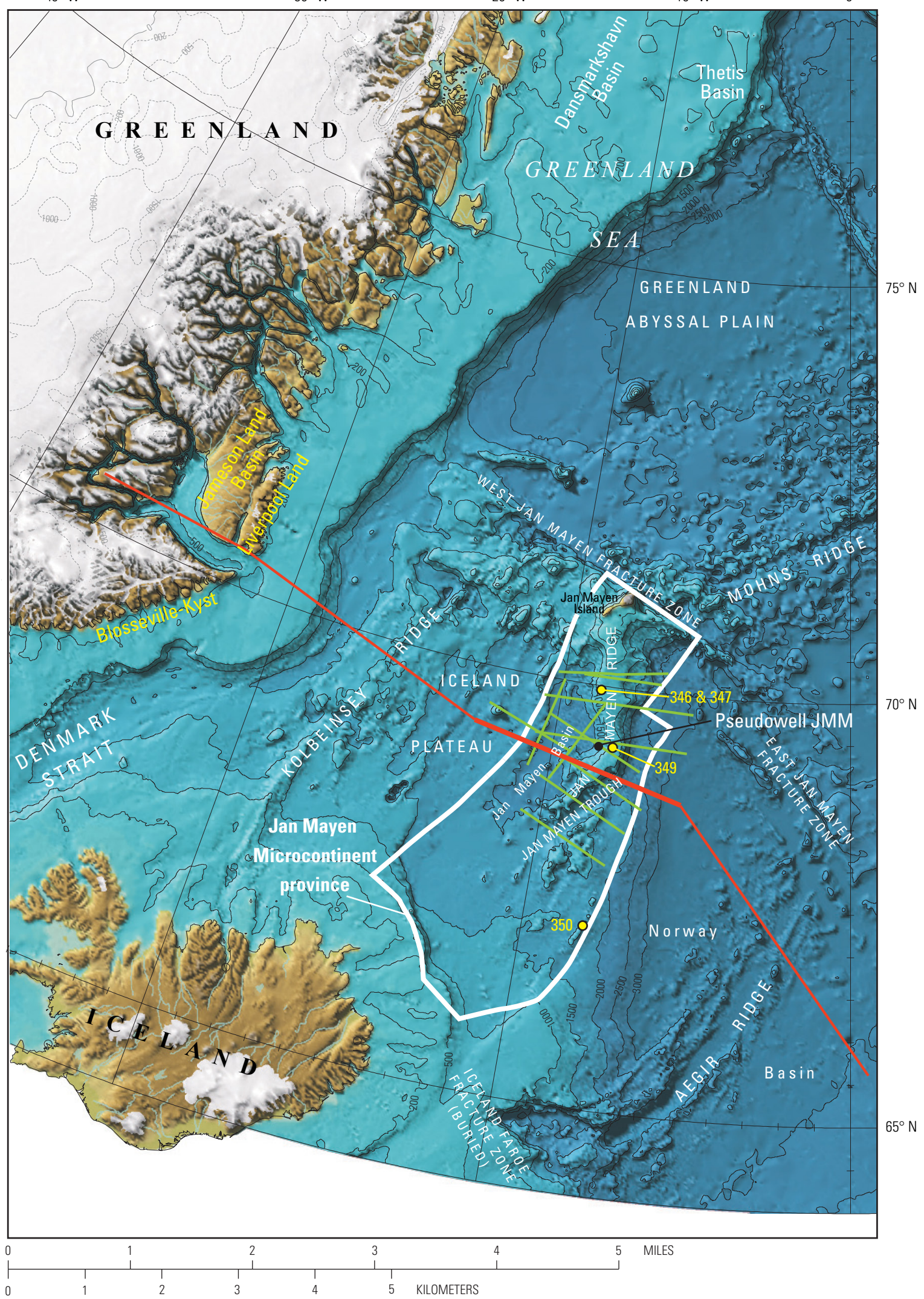

Figure 1. Bathymetric map of the North Atlantic Ocean (modified from Jakobsson and others, 2004) showing regional location of Jan Mayen Microcontinent and other features mentioned in text. White line, boundary of the Jan Mayen Microcontinent petroleum province; green lines, publically available seismic lines; thin red line, cross section of Sigmond (2002); heavy red line, location of cross section shown in figure 3; yellow circles, locations of DSDP drill sites and numbers; black circle, location of pseudowell JMM (fig. 4). 
A. Chron 24B (57 Ma)

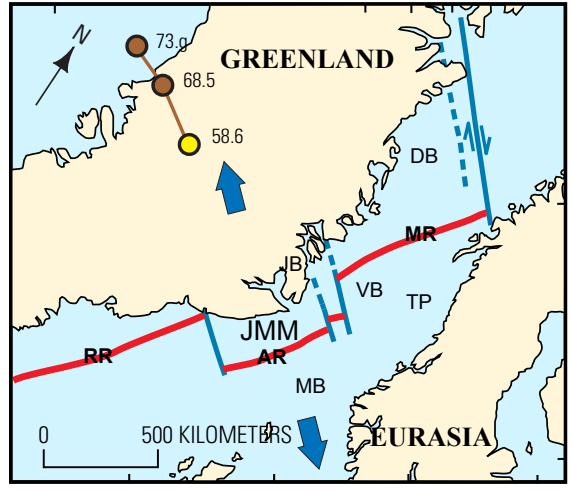

C. Chron 6 (20 Ma)

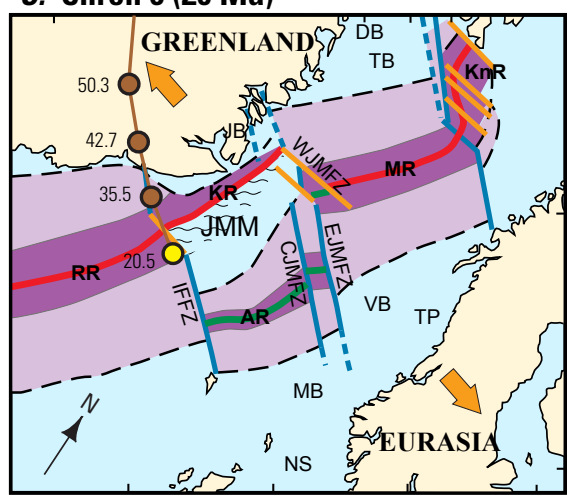

B. Chron 13 (35.5 Ma)

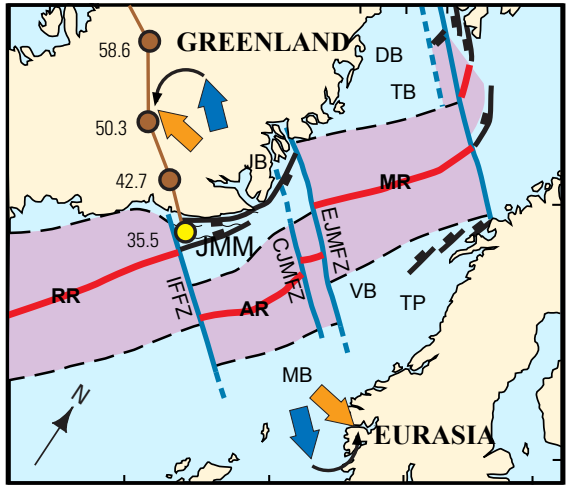

D. Present

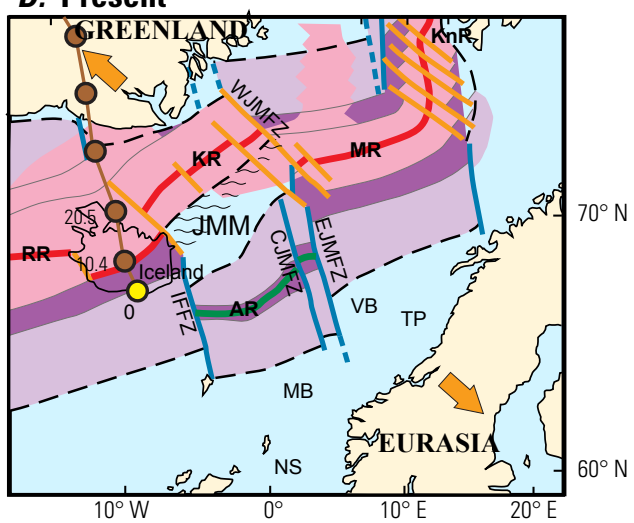

EXPLANATION

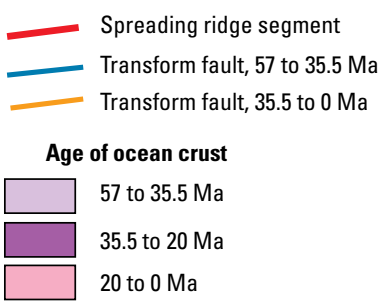

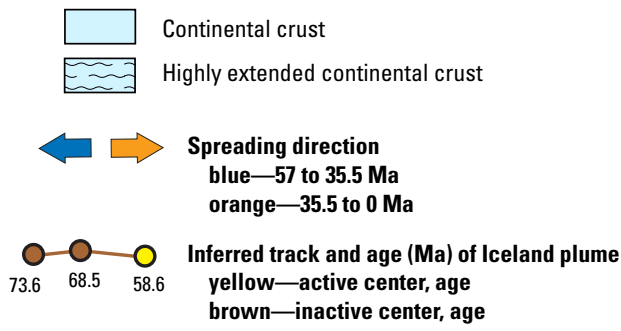

Figure 2. Plate tectonic origin of the Jan Mayen Microcontinent (JMM) and the inferred track of the Iceland plume in the Cenozoic (modified from Lundin and Doré, 2002). A, Position of the JMM between East Greenland and western Norway prior to the initiation of seafloor spreading in the North Atlantic. B, North Atlantic partially opened at Aegir spreading center prior to ridge jump to Kolbeinsey spreading center; change of spreading direction at $35.5 \mathrm{Ma}$ indicated by blue and orange arrows and orientation of blue and orange (in $C$ and $D$ ) transform faults. $C$, Separation of JMM away from margin of Greenland on Kolbeinsey spreading center nearly completed. $D$, JMM located in the central part of the North Atlantic Ocean as an isolated continental fragment and bounded to the south by the Iceland large igneous province (LIP). AR, Aegir Ridge; DB, Dansmarkshavn Basin; KnR, Knipovitch Ridge; KR, Kolbensey Ridge; MR, Mohn Ridge; MB, Møre Basin; RR, Reykjanes Ridge; NW, North Sea; TB, Thetis Basin; TP, VB, Vøring Basin. EJMFZ, East Jan Mayen Fracture Zone; CJMFZ, Central Jan Mayen Fracture Zone; WJMFZ, West Jan Mayen Fracture Zone; IFFZ, Iceland-Faroe Fracture Zone. Ma, millions of years before present.
Paleocene prior to its arrival in eastern Greenland, as indicated by the voluminous continental flood basalts in southeastern Greenland and correlative thick, passive margin sequences of basalts visible as seaward-dipping reflectors in seismic profiles in the margins of Greenland, Norway, the Rockall Plateau, and eastern Jan Mayen Land (Eldholm and Grue, 1994). The Iceland LIP itself can be traced bathymetrically via the IcelandDenmark Ridge to Greenland and also across the Aegir Ridge to the Eurasian margin of the North Atlantic via the IcelandFaroe Ridge, indicating a direct tie between the Iceland LIP and the Paleocene magmatism on the continental margins. The Iceland hotspot, however, is thought to have been located in western Greenland at this time. For this reason, the magmatism in the North Atlantic has been considered to be a far-field rather than direct effect of the Iceland plume (Eldholm and Grue, 1994; Gudlaugsson and others, 1988; Lundin and Doré, 2002; Mosar and others, 2002; Mjelde and others, 2008).
Because the Iceland LIP and other magmatic features of the North Atlantic are thought to be due to a hotspot or plume, some have suggested that a broad zone of lithosphere near the LIP was thinned by additional heating, producing the highly attenuated lithosphere in parts of the southern Jan Mayen Microcontinent (Mosar and others, 2002; Mjelde and others, 2008). Some workers have concluded that the plume magmatism itself was the trigger for the rifting and seafloor spreading in the North Atlantic in the Paleogene as well as the ridge jump from the Aegir to the Kolbeinsey spreading ridges in the Eocene and Oligocene (Mosar and others, 2002; Müller and others, 2001; Mjelde and others, 2008). On the other hand, Foulger and others (2005) and Lundin and Doré (2005) concluded that the extensive magmatism in Iceland and the North Atlantic margin was not related to plume magmatism and instead attributed it to normal seafloor spreading processes enhanced by the presence of an unusually fertile mantle. Their 
model would not predict unusually elevated regional geotherms, and instead links the sites of voluminous magmatism to rift zones and spreading centers developed by normal midocean ridge plate tectonic processes.

\section{Province Structure and Stratigraphy}

Seismic reflection studies show that the Jan Mayen Microcontinent is an asymmetric continental fragment (Gudlaugsson and others, 1988) (fig. 3). Its eastern margin is an east-facing passive margin that developed beginning at $\sim 57 \mathrm{Ma}$ and is the conjugate margin to the Møre and FaroeShetland (fig. 1) basins of the Norwegian continental margin. The western margin is a passive margin developed in the Oligocene and Miocene by the seafloor spreading at the Kolbeinsey Ridge. This margin is the conjugate margin to the eastern Greenland continental margin at Liverpool Land and Blosseville Kyst. Although both sides of the microcontinent are passive margins, the two margins differ significantly in structural and stratigraphic style and have different thermal and mechanical characteristics.

The eastern margin is a structurally intact volcanic-type margin that is marked by a sequence of seaward-dipping reflectors. The sequence is floored by a thick succession of flood basalts and an overlying eastward-prograding sedimentary package that was deposited while the microcontinent was still part of Greenland prior to seafloor spreading on the Kolbeinsey Ridge (Talwani and Eldholm, 1977; Gudlaugsson and others, 1988). Seismic reflection data indicate that fault blocks of Mesozoic sedimentary rocks may exist beneath the volcanic rocks (Kuvaas and Kodaira, 1997). Uplift and erosion at the time of the formation of the Kolbeinsey Ridge across the Greenland margin in the late Eocene and early Oligocene produced an unconformity that is overlain by a postrift sedimentary succession of late Oligocene and younger age (Talwani and Eldholm, 1977; Gudlaugsson and others, 1988, Kuvaas and Kodaira, 1997). The late Oligocene and younger strata are pelagic and hemipelagic strata interpreted to have been deposited after rifting of the Jan Mayen Microcontinent from Greenland (Gudlaugsson and others, 1988).

The western part of the microcontinent is regionally faulted into west-facing, eastward-rotated half-grabens and extensional fault blocks. The number of fault blocks and the general complexity of the structure increase southward in the microcontinent and the structural relief similarly diminishes in the same direction (Gudlaugsson and others, 1988). The continental crust is as much as $20 \mathrm{~km}$ thick in undeformed parts of the Jan Mayen Ridge, but diminishes in thickness to as little as $8 \mathrm{~km}$ along the western margin of the microcontinent (Kodaira and others, 1998). Areas having extremely thin continental crustal sections or transitional continent-oceanic crust are more widespread in the south, where the microcontinent is the widest and is thought to have undergone higher amounts of extension (Lundin and Doré, 2002). Although sills and (or) lava flows are recognized in seismic data, extensive packages of volcanic rocks are mostly absent, and this margin is classified as a continental margin of nonvolcanic type (Gudlaugsson and others, 1988).
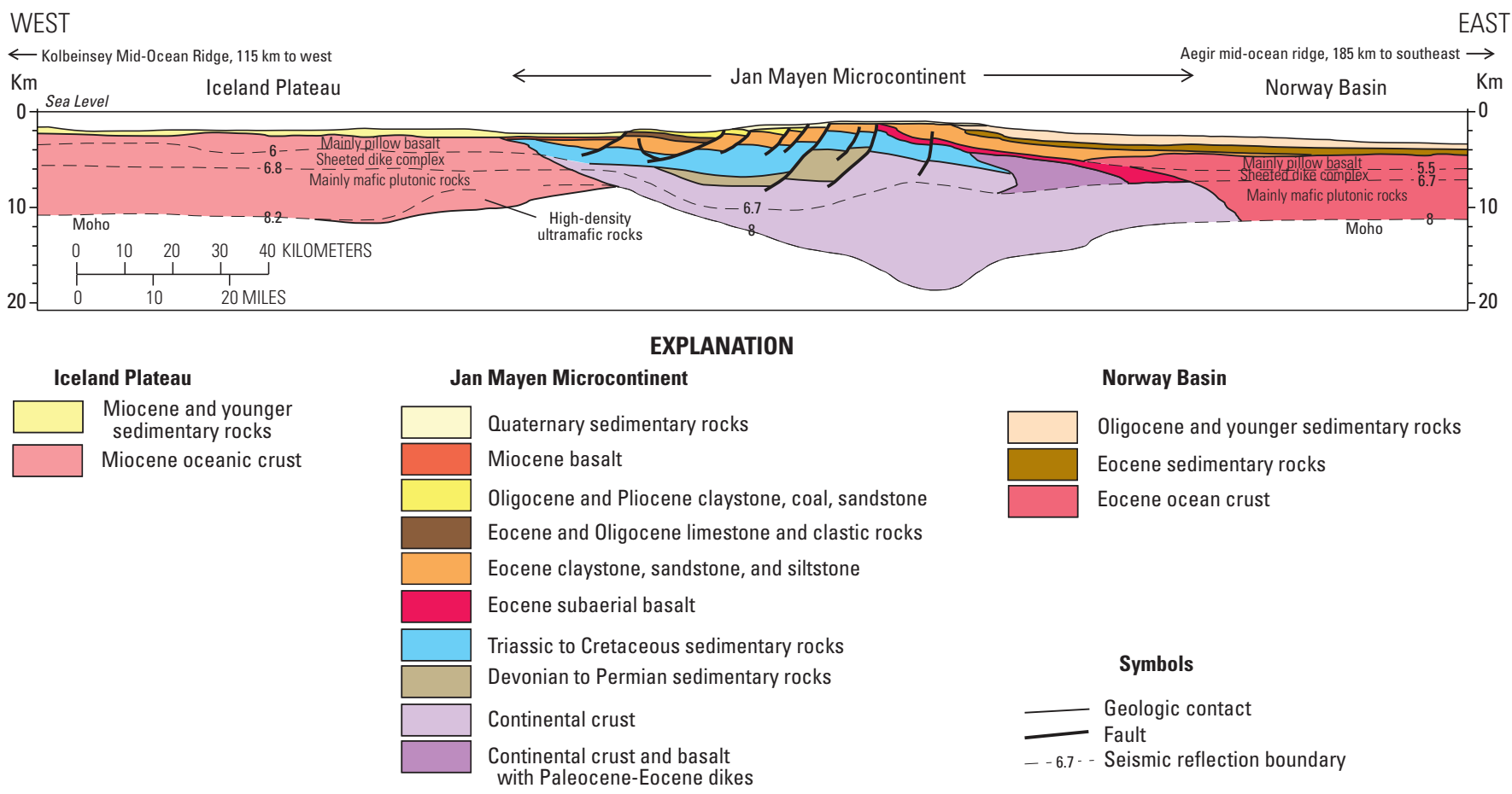

Eocene and Oligocene limestone and clastic rocks

Eocene claystone, sandstone, and siltstone

Eocene subaerial basalt

Triassic to Cretaceous sedimentary rocks

Devonian to Permian sedimentary rocks

Continental crust and basalt

with Paleocene-Eocene dikes 
Information about the stratigraphy of the microcontinent is limited to that obtained from four scientific cores recovered by the Deep Sea Drilling Project (DSDP) on Jan Mayen Ridge (Talwani and others, 1976) and seismic refraction studies (Gudlaugsson and others, 1988, Kuvaas and Kodaira, 1997; Kodaira and others, 1998). DSDP drill sites 346 and 347 are within 1 nautical mile of each other on the northern part of Jan Mayen Ridge (fig. 1). The drilling at these sites revealed Pliocene and Pleisocene terrigenous sandy mud and mud and clay that is underlain by middle Miocene sandy mud and biogenic siliceous oozes characterized by high percentages of sponge spicules. Indurated, massive late Eocene terrigenous sandy mudstone forms the lowermost part of the drilled sections. DSDP drill site 349, on the central part of Jan Mayen Ridge, displays a similar Miocene to Pleistocene section as that at sites 346 and 347. Beneath the Miocene sediments are glauconitic Oligocene muds and sandy muds with volcanic ash in the upper part. The lower part of the drilled section consists of upper Eocene to lower Oligocene mudstone, sandy mudstone, conglomeratic sandstone and breccia that is tilted relative to the overlying Miocene and younger section (Talwani and others, 1976). DSDP drill site 350, on a basement ridge at the southwestern margin of the Jan Mayen Microcontinent, consists of an upper sedimentary unit of Pleistocene and Pliocene sandy mud, a middle sedimentary unit of middle Miocene and Oligocene locally lithified clay and mud, and a lower sedimentary unit of Oligocene and late Eocene claystone, mudstone, breccia, and pebbly sandstone turbidites in the lower part of the unit (Talwani and others, 1976). The sedimentary units are underlain by marine volcanic breccias and massive basalt dated at 40-44 Ma at the bottom of the $388 \mathrm{~m}$ thick section (Talwani and others, 1976).

The scientific cores recovered on Jan Mayen Ridge document an unconformity that separates late Eocene and early Oligocene turbidites from overlying late Oligocene and Miocene hemipelagic deposits and Pleistocene glacial marine deposits (Talwani and others, 1976). The unconformity, marked by a basal conglomerate in the Miocene section at drill site 349, is thought to record rift-related uplift and erosion of the Jan Mayen Microcontinent during breakup at the Kolbeinsey Ridge (Talwani and Eldholm, 1977; Gudlaugsson and others, 1988, Kuvaas and Kodaira, 1997). The section at DSDP drill site 350, on the other hand, reflects deposition of coarse-grained turbidites on basalt that are replaced upward by by hemipelagic mudstone, biogenic calcareous and siliceous oozes, and finally by glacial-marine sediments indicative of deposition in a widening oceanic basin on transitional continental crust or oceanic seafloor (Nilsen and Kerr, 1978). Regionally extensive basalts and (or) sills in Miocene deposits appear to cover wide areas of the western part of the microcontinent and diminish the quality of seismic data over much of this part of the province (Gudlaugsson and others, 1988).

The refraction studies in the northern part of the province suggest that Mesozoic and Paleozoic sedimentary deposits may be present beneath covering Cenozoic sediments (Kuvaas and Kodaira, 1997; Kodaira and others, 1998). The Mesozoic deposits are inferred to consist of strata deposited in extensional basins such as those in the Jurassic and Cretaceous Vøring and Møre Basins that developed prior to continental breakup in the North Atlantic (Mjelde and others, 2008; Nøttvedt and others, 2008). Devonian to lower Permian posttectonic platform strata deposited following the end of the Caledonian orogeny and Permian and Triassic rift basin deposits may also be present (Kuvaas and Kodaira, 1997). These sequences form a series of elongated, north-south-trending, fault-bounded basins in eastern Greenland, along the continental margin of Norway, and in the North Sea. These basins originated during the Devonian as a result of extension and rifting between Greenland and Norway following the Silurian and Devonian Caledonian deformational event (Doré, 1991; Stemmerik, 2000, Nøttvedt and others, 2008) and renewed episodic rifting in the late Permian and the Mesozoic by extensional processes that eventually led to opening of the North Atlantic Ocean in the Paleocene (Coward and others, 2003).

The structural and stratigraphic architecture of the Jan Mayen Microcontinent is similar to that of the northeastern margin of Greenland as described by Hamann and others (2005). The Thetis Basin, which lies along the continentocean boundary of northeastern Greenland, was formed during continental breakup in the late Paleocene. Although it lacks a seaward-dipping sequence of volcanic rocks, the basin lies in a conjugate structural position to the east-facing rift margin of the Jan Mayen Microcontinent. To the west and inboard of an uplifted ridge of basement rocks bounding the western margin of Thetis Basin, the Dansmarkshavn Basin is a rift basin filled with Devonian to Cretaceous strata. These rocks plunge southward beneath early Paleogene flood basalts toward Liverpool Land. The northern part of the Jan Mayen Microcontinent was located near Liverpool Land prior to its being rifted away from the continental margin in the Oligocene and Miocene (Hamann and others, 2005; fig. 3). If Dansmarkshavn Basin also once extended farther south beneath covering basalts, its southern part might have been rifted away as part of the Jan Mayen Microcontinent and could be represented by the Upper Paleozoic and Mesosoic rocks identified in the refraction seismic data. Alternatively, if Dansmarkshavn Basin did not extend southward to the area that was rifted away to form the Jan Mayen Microcontinent, it is possible that another basin of similar architecture may have been present in this area. Jameson Land Basin, a basin similar to Dansmarkshavn Basin that lies east of Liverpool Land, shows that other large faultbounded basins were once present along the margin of this part of eastern Greenland (Hamann and others, 2005).

The youngest rocks in the Jan Mayen Microcontinent are the LIP volcanic deposits found on Jan Mayen Island adjacent to the West Jan Mayen Fracture Zone at the north end of the continent. These volcanic rocks have been interpreted to comprise a local volcanic field erupted along a "leaky" fracture zone (Lundin and Doré, 2005) or alternatively, a local volcanic edifice built by magmatism derived from the Iceland plume (Mjelde and others, 2008). Because isotopic data from basalts from Jan Mayen Island show little or no interaction 
with continental rocks, some workers have concluded that Jan Mayen Ridge north of the Central and (or) East Jan Mayen Fracture Zones comprises an oceanic plateau that lacks any underlying continental crust (Scott and others, 2005; Mjelde and others, 2008; Gaina and others, 2009). The volcanic rocks instead are regarded here as being underlain by continental crust or continental crust heavily intruded by LIP magmatic rocks (Lundin and Doré, 2005) because the volcanic edifice appears to lie on the northward continuation of Jan Mayen Ridge, as expressed by bathymetry and potential field data.

Although deformation in the Jan Mayen Microcontinent is predominantly extensional, inversion and contractional structures have been reported locally (Gulaudsson and others, 1988). Low-displacement contractional deformation and tectonic inversion of mid-Cenozoic age have been recognized on the Norwegian and Greenland margins, locally forming traps for hydrocarbons (Lundin and Doré, 2002). The contractional structures have been ascribed to a variety of causes, including far-field affects of the Alpine deformational belt, changes in spreading rates, and the hypothesized Iceland plume (Lundin and Doré, 2002; Tuitt and others, 2010).

\section{Petroleum Systems}

No petroleum systems have been identified in the province. Possible indications of gas, including amplitude anomalies and pockmarks, have been noted on a seismic section in the southern part of the microcontinent (Iceland GeoSurvey, 2008), but there are few other reports of hydrocarbon indicators in the literature for this region.

Although active petroleum systems have not been identified, the regional setting of the province in the North Atlantic region provides reason to believe that one may exist. Prior to opening of the North Atlantic, the Jan Mayen Land Microcontinent was located adjacent to the geological units of the northern North Sea and likely shares many of the same Paleozoic and Mesozoic stratigraphic and structural characteristics of the North Sea oil fields, including source rocks, reservoirs, and traps.

The principal source rock unit for the North Atlantic region is the world-class Upper Jurassic Kimmeridge Clay Formation and equivalent units (for example, the Spekk Formation in Norway, Hareelv and Bernbjerg Formations in East Greenland) (Thomas and others, 1985; Errat and others, 2010). The Kimmeridge Clay was deposited in rift grabens having restricted circulation during a sea-level high stand, which produced locally thick units of shale formed under anoxic conditions (Fraser and others, 2003). In the North Sea, the Kimmeridge Clay yields total organic carbon (TOC) values that average about 6 percent and locally are in excess of 10 percent and have hydrogen indicies ranging typically from $100-400 \mathrm{mg} / \mathrm{g}$ TOC (Kubala and others, 2003). In Norway, the correlative Spekk Formation is oil-prone, with average TOC values between 6 and 8 percent and hydrogen indices (HI) commonly greater than $350 \mathrm{mg} / \mathrm{g}$ TOC (Barnard and Bastow,
1991). In East Greenland, the correlative Hareelv and Bernbjerg Formations have TOC values of 2 to 13 percent with HI of 100 to $250 \mathrm{mg} / \mathrm{g}$ TOC, although HI values from the Bernbjerg Formation are mostly below $100 \mathrm{mg} / \mathrm{g}$ TOC, indicating a gas-prone source (Christiansen and others, 1992). These deposits tend to have higher TOC and HI values in the deeper parts of the structural troughs and lower values in more proximal areas, but may form richer deposits in the medial region between East Greenland and Norway (Christiansen and others, 1992, fig. 3d). The organic-rich rocks of the Kimmeridge Clay and related units are recognized in seismic data across wide regions of the Norwegian margin and are the sole volumetrically significant source rock unit present in that area (Swiecicki and others, 1998). Although highly productive in uplifted parts of that margin, the source rocks are commonly deeply buried and are overmature in the outer parts of that margin (Swiecicki and others, 1998). Where known from outcrops in Jameson Land in East Greenland, these strata preserve indications of having been heated to oil-window temperatures (Hansen and others, 2001). Oil seeps in East Greenland confirm that a petroleum system generated from an Upper Jurassic source rock similar to those known from Norway is present (Requejo and others, 1989). Hydrocarbon generation began in the Late Cretaceous or early Paleocene and continued throughout the Cenozoic in the North Sea due to continued burial (Baird, 1986). In East Greenland, however, fission-track data show that the time of maximum burial occurred at 55 to $20 \mathrm{Ma}$, following eruption of voluminous rift-related volcanic rocks in the Paleocene. Subsequent cooling and erosion was related to uplift caused by the onset of rifting on the Kolbeinsey Ridge.

Other organic, carbon-rich rock units that could have sourced oil and gas in the province include the upper Permian, Lower Jurassic, Cretaceous, and Paleocene strata. The upper Permian strata contain a net source rock thickness of 15 to $20 \mathrm{~m}$ and are widespread throughout East and Northeast Greenland (Christiansen and others, 1992). These strata were deposited in restricted marine basins fringed by carbonate deposits and contain an average of about 4 percent TOC. The Lower Jurassic organic units are also thin (10 to $15 \mathrm{~m}$ ) and have an average TOC of 6 percent. These shales are less extensive and were formed in a freshwater lake that once covered much of Jameson Land in East Greenland (Christiansen and others, 1993). The presence of source-rock-quality units in Cretaceous and Paleocene strata, on the other hand, has not been proven. Shale-dominated successions in thick marine units are widespread in these strata, suggesting that organic-rich source rock units eventually could be discovered (Swiecicki and others, 1998).

Considering that the Upper Jurassic source rock units of Norway and Greenland were contiguous prior to formation of the Atlantic Ocean in the Paleogene and contained parts of a once extensive region of transgressive, anoxic Late Jurassic rift-basin shale, it seems likely that similar deposits can be expected to be present in the Jan Mayen Microcontinent Province. In the North Sea, reservoir facies were deposited 
as a consequence of a broad continental to marine transition in the Triassic to Late Jurassic and include Middle Jurassic shallow marine to deep-marine sandstones deposited with synrift fanning geometries (Fraser and others, 2003, Erratt and others, 2010). Clastic deposits shed from the margins of the basin are also interstratified with the source rocks that overlie the continental succession in Jameson Land (Christiansen and others, 1992) and may form stratigraphic traps in the province. The major trap types in the province, however, are expected to be primarily structural, stratigraphic, and combination traps in the footwalls and hanging walls of rotated half-grabens and tilted fault blocks of Middle Jurassic and older strata formed during rifting at the end of the Jurassic after deposition of the source rocks (Fraser and others, 2003). Following tilting, thick successions of mudstone were deposited across remnant rift topography as a consequence of passive subsidence and rapid sedimentary infill in the Early Cretaceous and form sealing geometries (Erratt and others, 2010). Sparse, deep-marine sandstone intervals encased in the mudstone potentially also have reservoir quality and trapping geometry for sedimentary traps as in the North Sea (Copestake and others, 2003).

\section{Burial History}

A full understanding of the petroleum potential of a region can be reached only if its thermal and burial history is known. In the absence of any well data and only a limited seismic database that would provide information about its stratigraphy and thermal history, such insight is difficult to attain for Jan Mayen Microcontinent. In an effort to place constraints on the burial history of the microcontinent, we have used the available information to construct a one-dimensional model for pseudowell JMM on the west flank of Jan Mayen Ridge (figs. 1 and 4). This location was selected because of the availability of seismic data, the presence of relatively thick and structurally intact crust, and the interpretation that
Paleozoic-Mesozoic strata may be present (Kodaira and others, 1998) (fig. 3).

On the basis of their seismic refraction data, Kodaira and others (1998) proposed that the crustal section at the pseudowell is $12 \mathrm{~km}$ thick and consists of about $1.5 \mathrm{~km}$ of Cenozoic sediments, $1.5 \mathrm{~km}$ of Mesozoic sediments, $2.2 \mathrm{~km}$ of Paleozoic sediments, and $7 \mathrm{~km}$ of continental crust that likely consists of deformed metamorphic and igneous rocks formed during the Caledonian orogeny. Using this crustal section and by comparison principally with the stratigraphy of East Greenland (Stemmerik and others, 1992; Christiansen and others, 1993; Larsen and others, 1999; Mathiesen and others, 1995, 2000; Henriksen and others, 2000) and with reference to the stratigraphy of the North Sea and Norwegian margin (Swiecicki and others, 1998), we propose a speculative stratigraphic section for this part of the Jan Mayen Microcontinent (table 1). Seawarddipping reflectors interpreted as Paleogene flood basalts related to the Iceland plume are present on the eastern flank of the Jan Mayen Microcontinent (Myhre and others, 1984; Gudlaugsson and others, 1988) and a thick pile of basalts thought to be their updip equivalents prior to rifting of the Jan Mayen Microcontient away from the Greenland continental margin is present in eastern Greenland (Mathiesen and others, 2000). Seismic data, however, indicate that such basalts are absent in the area of the pseudowell, which suggests that the volcanic succession was removed by erosion, possibly during rifting associated with formation of the Kolbeinsey Ridge in the Eocene (fig. 3). A total of 2 to $4 \mathrm{~km}$ of erosion occurred following maximum burial at about $35 \mathrm{Ma}$ in the area of Jameson Land and Liverpool Land (Mathiesen and others, 2000; Hansen and others, 2001).

For our burial history model (fig. 4), we have assumed a constant heat flow of 60 milliwatts per square meter $\left(\mathrm{mW} / \mathrm{m}^{2}\right)$ for the time period of 300 to $55 \mathrm{Ma}$, reflecting a continental interior depositional environment that was influenced by sporadic rifting and extensional deformation. During the interval 55 to $20 \mathrm{Ma}$, we hypothesized increased heat flow at $80 \mathrm{~mW} / \mathrm{m}^{2}$

Table 1. Stratigraphic model used to construct burial history model for pseudowell JMM.

\begin{tabular}{lccclc}
\hline Unit & $\begin{array}{c}\text { Unit age (millions } \\
\text { of years ago) }\end{array}$ & $\begin{array}{c}\text { Duration (millions } \\
\text { of years) }\end{array}$ & $\begin{array}{c}\text { Unit thickness } \\
\text { (meters) }\end{array}$ & Lithology & Tectonics \\
\hline 1 & $20-0$ & 20 & 300 & Pelagic siltstone and mudstone & Passive margin \\
2 & $35-20$ & 15 & 1,200 & $\begin{array}{c}\text { Alluvial to shallow marine mudstone and } \\
\text { conglomerate }\end{array}$ & Rifting \\
Erosion & $52-35$ & 17 & $-2,500$ & -- & Rifting \\
3 & $55-52$ & 3 & 1,000 & Basalt flows & Rifting \\
4 & $97-55$ & 42 & 1,500 & Deep-marine mudstone and sandstone & Rifting, LIP volcanism \\
5 & $125-97$ & 28 & 200 & Deep-marine mudstone and sandstone & Extension \\
6 & $151-125$ & 26 & 100 & Shallow-marine sandstone and mudstone & Extension \\
7 & $156-151$ & 5 & 200 & Organic-rich shale & Extension \\
8 & $168-156$ & 12 & 500 & Sandstone and mudstone & Extension \\
9 & $251-168$ & 83 & 500 & Sandstone, shale, halite & Extension \\
11 & $362-251$ & 111 & 1,000 & Sandstone, carbonate, halite & Stable shelf \\
\hline
\end{tabular}




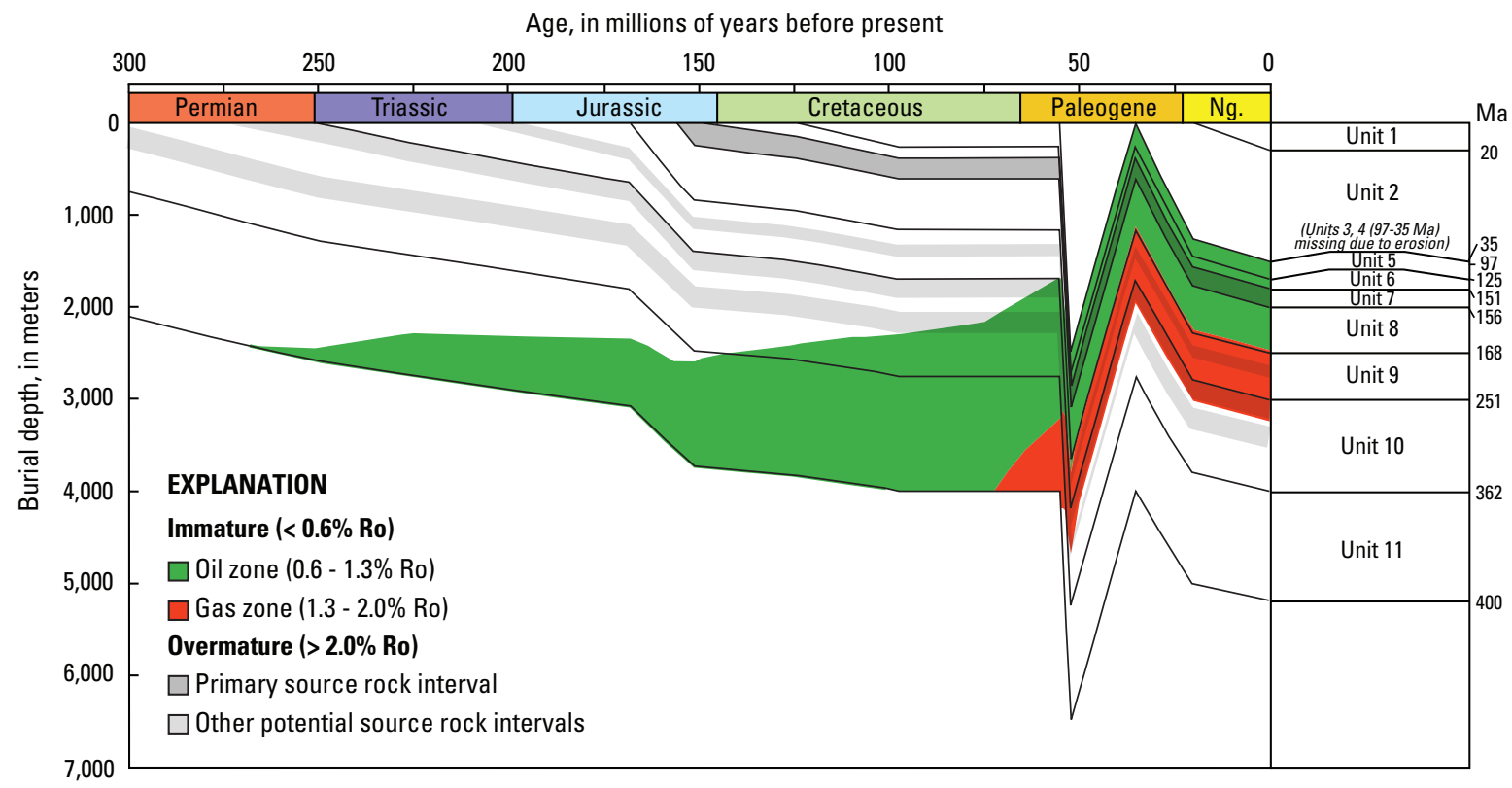

Boundary parameters

Age, in millions of years before present Temperature, in degrees Celsius Vitrinite reflectance, in percent
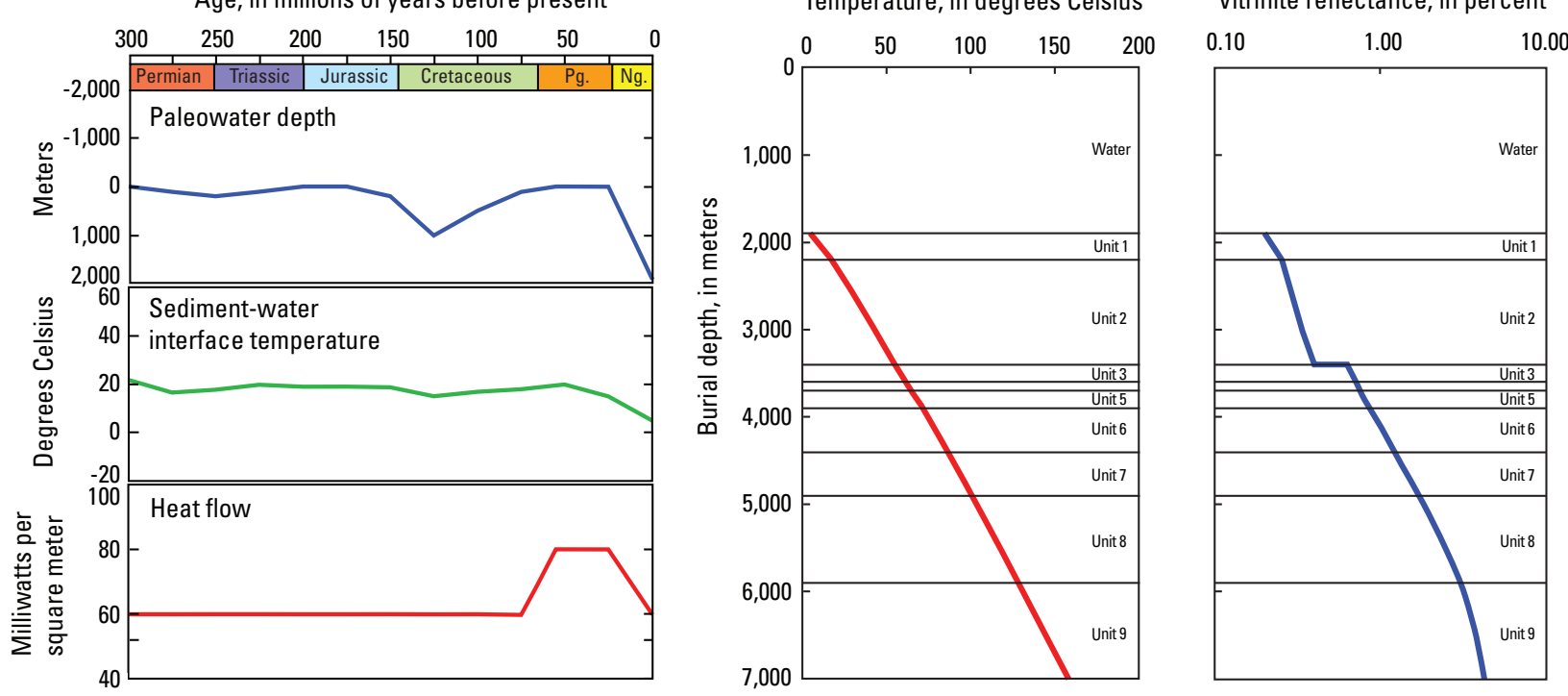

Figure 4. Burial history model for pseudowell JMM located on west flank of Jan Mayen Ridge at $8.548^{\circ} \mathrm{W}, 69.273^{\circ} \mathrm{N}$ (see fig. 1 for location). See table 1 for stratigraphic model used to construct the diagram. Thermal history modeled using publicly available software (Integrated Exploration Systems, 2008). Source rock strata shown as shaded intervals in burial history model, with dark shading indicating Upper Jurassic source rocks. Model suggests that Upper Jurassic source rocks entered oil window at time of maximum burial beneath Paleocene-Eocene basalt but experienced more than 2 kilometers of denudation later in the Paleogene. Ma, millions of years before present; $\mathrm{Ng.,}$ Neogene; Pg., Paleogene; Ro, vitrinite reflectance, in percent (\%). 
because of onset of seafloor spreading in the North Atlantic and the extensive magmatism related to the Iceland LIP. After $20 \mathrm{Ma}$, we have assumed a monotonic decline back to $60 \mathrm{~mW} / \mathrm{m}^{2}$ in the Holocene to reflect the passive tectonic environment of the microcontinent following the rifting and onset of spreading on the Kolbeinsey Ridge. This heat flow history is similar to that used for modeling hydrocarbon generation in East Greenland by Mathiesen and others (2000), although in comparison we have used (1) a value closer to world averages for the heat flow of continental interiors (Allen and Allen, 2005) for the time before $55 \mathrm{Ma}$ and (2) a more protracted period of high heat flow in the Paleocene to capture the combined thermal effects of LIP magmatism and rifting related to both the Aegir and Kolbeinsey Ridges.

The resulting model suggests that maturation of the source-rock section increased slowly in parallel with deposition in the early Mesozoic and at a somewhat faster rate in the Cretaceous as the rate of deposition increased due to rifting in advance of seafloor spreading in the Paleocene. Source rocks that may be present in Paleozoic strata would have entered the oil window but Triassic and Jurassic source rocks remained immature at this time. The model suggests that the latter strata would not have entered the oil window until the time of maximum burial of the section in the late Paleocene or early Eocene following deposition of an estimated thickness of $1 \mathrm{~km}$ of basalt and the change to a higher heat flow. Maturation during this time would have produced oil in the Upper Jurassic source rock strata, gas in Permian and Lower Jurassic source rock strata, and any Carboniferous source rock strata would be overmature. Later in the Eocene, however, the uplift and erosion related to rifting in advance of the separation of the Jan Mayen Microcontinent from Greenland resulted in a deep level of erosion that removed all of the Paleogene volcanic rocks and much of the underlying Cretaceous section. Presumably, any petroleum accumulations generated at the time of maximum burial would have undergone significant amounts of gas expansion by the end of the Eocene as a result of the rift-related uplift and erosion. Subsequent deposition has acted simply to rebury the source rock strata without restarting petroleum generation in any of the strata.

\section{Assessment Unit}

Assessment units (AUs) used for the CARA study closely follow the structural elements present in the constituent provinces because the structural architecture controls the location, extent, and configuration of the sedimentary basins that may be prospective for hydrocarbons (Grantz and others, 2010, 2011). The thickness, stratigraphy, facies, burial history, and structural evolution of the basins affect the size, number, and timing of formation of potential petroleum traps and petroleum generation and migration in the province. Because the Jan Mayen Microcontinent Province displays a shared stratigraphic framework and history of multiple rifting events throughout it extent, the entire province is assigned to a single assessment unit, the Jan Mayen Microcontinent AU.

\section{Jan Mayen Microcontinent AU}

The Jan Mayen Microcontinent AU (USGS assessment code 52010101) contains no petroleum exploration wells and very sparse seismic data. This level of exploration places this AU into uncertainty category 4 on the scale used by the USGS for the Circum-Arctic Resource Appraisal (Charpentier and Gautier, 2011).

\section{AU Description}

The Jan Mayen Microcontinent AU is an area of approximately $116,000 \mathrm{~km}^{2}$. The AU is mostly submarine, with water depths typically ranging from $300 \mathrm{~m}$ on Jan Mayen Ridge to greater than 2,000 $\mathrm{m}$ in Jan Mayen Basin and in the ocean basin along the eastern margin of the AU. Jan Mayen Island in the northernmost part of Jan Mayen Ridge is a $\sim 350 \mathrm{~km}^{2}$ volcanic edifice formed on the ridge in the Pleistocene and Holocene by basaltic volcanic rocks, and is the only part of the AU that lies above sea level. The AU is flanked on the north, east, and west by ocean crust of the North Atlantic Ocean and by the basaltic volcanic rocks of Iceland to the south. The AU consists of several ridges and basins formed by extensional processes, the largest of which is the high-standing, northsouth trending Jan Mayen Ridge. This ridge diminishes in elevation southward and is replaced by several smaller ridges of lower relief. The ridges and intervening basins are thought to consist of a continental crustal section similar to that of northeastern Greenland. The crustal section was strongly extended by subsequent basin-and-range processes in the Paleogene and early Neogene, with some basins having crustal thicknesses reduced to near those of oceanic crust. Post-extensional (Neogene) sediments mantle the ridges and basins and include volcanic rocks and (or) volcanic sills across wide areas of the AU.

\section{Geological Model for Assessment}

The geologic model for assessment of the Jan Mayen Microcontinent AU is based on the hypothesis that it shares a stratigraphy and structural setting with the prolific petroleum provinces of Norway and the North Sea and highly prospective basins in eastern Greenland (Gautier 2011b) (fig. 5). The model proposes that hydrocarbons generated from the Upper Jurassic Kimmeridge Clay Formation and possibly from upper Permian and Lower Jurassic source rocks attained temperatures necessary to mature hydrocarbons at the time of maximum burial in the Paleogene. The maturation and consequent expulsion of the hydrocarbons occurred during Paleogene rifting, allowing migration of hydrocarbons into tilted rift-related sandstone reservoirs of Lower Cretaceous age fault trap 


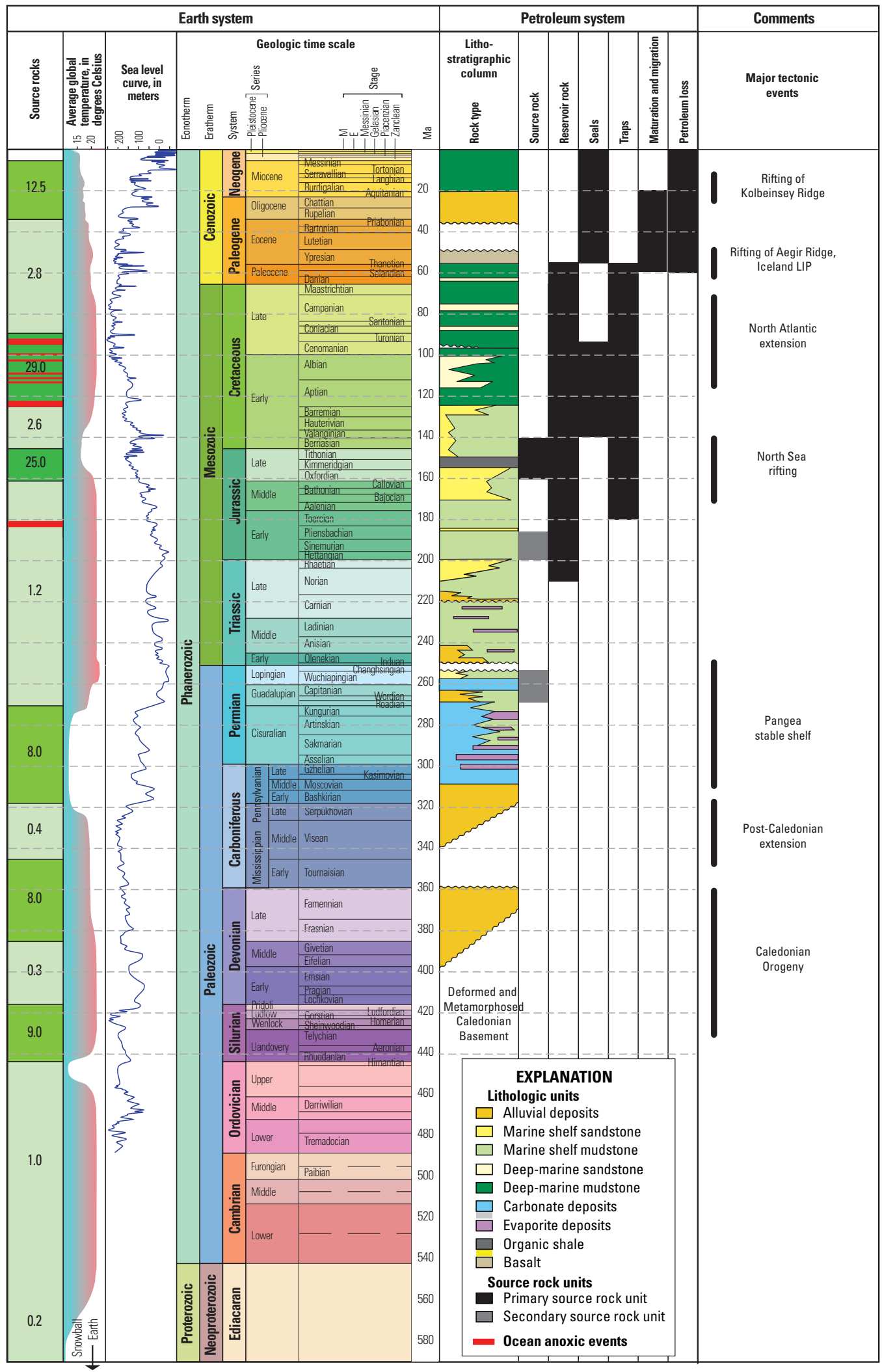

Figure 5. Inferred lithostratigraphic column for the Jan Mayen Microcontinent, showing petroleum-system elements and major tectonic events. Lithostratigraphy for Jan Mayen Microcontinent generalized from East Greenland (Hamann and others, 2005), North Sea (Erratt and others, 2010), and seismic data (Kodaira and others, 1998). Source rocks column at far left shows the percent of the world's total petroleum reserves generated by source (modified from Ulmishek and Klemme, 1990). Average global temperature data is from Frakes and others (1992) and Barrett (2003). Sea level curve is from Golonka and Kiessling (2002) and Hardenbol and others (1998). Geologic time scale is that of Gradstein and others (2004). 
settings. Lower Cretaceous shale-rich deposits unconformably overlap the tilted fault blocks and provide sealing configurations. Stratigraphic traps may also be present in channelized sandstones in progradational Cretaceous and Paleogene deposits. Structural traps in inversion anticlines formed during regional late Paleogene compressional deformation are also possible.

\section{Geological Analysis of Assessment Unit Probability}

The probability that the Jan Mayen Microcontinent AU contains at least one undiscovered accumulation of hydrocarbons equal to or greater than the minimum accumulation size of 50 million barrels of oil equivalent (MMBOE) was determined from its geologic and petroleum system characteristics as reviewed below.

Charge.-Although there is little direct evidence of an active petroleum system, there is a high probability that source rocks similar to the Upper Jurassic Kimmeridge Clay Formation are present in the AU. Correlatives of the Kimmeridge Clay are present on both the Norway continental margin (Spekk Formation) and in East Greenland (Hareelv and Bernbjerg Formations). Because the Jan Mayen Microcontinent originated in close proximity to Norway, the North Sea, and Greenland prior to Mesozoic rifting in the North Atlantic region, the same depositional environments that produced those source rocks should have been present in the AU. In addition, upper Permian (Ravnefjeld Formation) and Lower Jurassic (Kap Stewart Formation) source rocks are known to be present in East Greenland (Christiansen and others, 1992; Mathiesen and others, 1995) and may also have been deposited in the AU. Burial history modeling shows that at the time of maximum burial, the Upper Jurassic shales were buried to depths required to cause petroleum generation, although such burial may have caused upper Permian and the Lower and Middle Jurassic source rocks, if present, to become overmature. Uncertainty about the presence of source rock facies (particularly beneath the seaward-dipping reflectors along the eastern margin of the AU), the generative potential of the source rocks (gas-prone marginal marine or oil-prone basinal deposits), and the extent and distribution of the source rocks in view of their deposition in isolated graben systems (for example, Zanella and Coward, 2003), resulted in a probability value of 0.4 being assigned to charge in the AU. The various hypothetical petroleum systems in the Jan Mayen Microcontinent AU are classified together as the Jan Mayen PaleozoicMesozoic composite total petroleum system (appendix 1).

Rocks.-Lower and Middle Jurassic sandstones, which form the largest and most important reservoirs in northwest Europe and have been demonstrated to form reservoirs in East Greenland (Price and Whitham, 1997), are postulated to comprise the most important reservoirs in the AU. The reservoirs are likely to be mostly wedge-shaped bodies of shallow marine and fluvial-deltaic deposits, based on analogy to the reservoirs demonstrated in other areas (for example, Husmo and others, 2003). Reservoirs facies may also be present in the Upper Jurassic source rocks themselves (for example, Fraser and others, 2003). The Hareelv Formation in Jameson Land Basin in East Greenland, for example, contains thin to thick, elongate sandstone bodies deposited by sedimentgravity flows that were derived from the basin margins and have excellent reservoir qualities (Requejo and others, 1989). Reservoir lithologies may also include Triassic sandstones and progradational Paleogene sandstones. Tilted fault-block trapping geometries beneath the regional unconformity at the base of the Cretaceous section are the primary trapping configuration for Jurassic reservoirs in the North Sea, the Norwegian margin, and in East Greenland (Swiecicki and others, 1998; Price and Whitham, 1997; Fraser and others, 2003; Erratt and others, 2010) and are proposed to be the principal trap style in this AU. Albian to Cenomanian shale units unconformably overlap the tilted fault blocks and are likely to provide sealing configurations. Other possible trapping configurations include unconformity/fault traps associated with Cretaceous, and (or) Paleogene extension, Cenozoic inversion anticlines along the western margin of the AU, and channelized sandstones forming stratigraphic traps in fans and progradational sequences of the Cretaceous and Paleogene basinal sequences of the province. A favorable probability of 0.7 was assigned for adequacy of reservoirs, traps and seals in this AU. The probability was diminished only because of questions about the stratigraphic architecture of the province and whether the Jurassic section could be partly or completely missing beneath the Cretaceous unconformity as has been observed in the North Sea and East Greenland (for example, Price and Whitham, 1997; Fraser and others, 2003).

Timing and Preservation.-Although the burial history modeling is favorable for the generation of hydrocarbons in the $\mathrm{AU}$, the preservation of oil generated from pre-Cenozoic source rocks is highly unfavorable because of subsequent extensional tectonism and magmatic events. The AU has been in close proximity to two sites of continental breakup: one in the Paleocene and Eocene along the eastern margin of the microcontinent, and one in the Oligocene and Miocene along its western margin. In East Greenland, the breakup events were accompanied by more than $2 \mathrm{~km}$ of denudation (Hansen and others, 2001; Mathiesen and others, 1995, 2000; Price and Whitham, 1997) and a similar amount can be hypothesized for the Jan Mayen Microcontinent. Consequent cooling, gas expansion, and oil displacement of any petroleum that may have accumulated likely would have occurred under such conditions. Subsequent extensional deformation related to seafloor spreading probably produced significant amounts of structural thinning, particularly in basins and in the southern part of the $\mathrm{AU}$. Therefore, the areas of greatest prospectivity are probably limited to the ridges of the AU because those areas are the most likely to contain largely intact stratigraphic successions. The pre-Cenozoic stratigraphic sections of basins, in contrast, are likely to be highly faulted domains such that any hydrocarbons once present probably escaped during faulting. 
In addition to the structural complications, the AU was affected by magmatic events that accompanied the two periods of continental breakup. In East Greenland, the PaleoceneEocene event resulted in the accumulation of thick sequences of basaltic volcanic rocks, dikes, and sills, whereas the Oligocene-Miocene event is represented by local syenite intrusions, dikes and sills, and broad hydrothermal zones. Hansen and others (2001) concluded that dikes and sills had only minor, local effects on the regional thermal evolution, whereas Price and Whitham (1997) concluded that Eocene and Oligocene magmatism resulted in a significant spike in heat flow and regional thermal degradation of hydrocarbons in the same rocks. Late Cenozoic magmatism in the Iceland LIP to the south and basaltic volcanism at Jan Mayen Island to the north lend additional uncertainties that complicate a full understanding of the thermal history of the AU.

Considering that the Jan Mayen Microcontinent is a small sliver of continental crust trapped between two Cenozoic oceanic basins and the other considerations discussed above, a probability of 0.2 was assigned as a measure of the adequacy of timing and preservation of one or more fields greater than the minimum size within this AU.

Overall Geologic Probability.-The geologic probability of the presence of an accumulation of minimum size in the Jan Mayen Microcontinent AU is the product of the three geologic probabilities discussed above, which results in an overall probability of 0.056 (appendix 1). This level of probability suggests that there is a 5.6 percent chance for the proper conditions to form at least one oil or gas accumulation of minimum size (50 MMBOE recoverable) in this AU. This level of probability, determined from the geology of the AU, was compared to the probabilities of other AUs in the Arctic region to ensure consistency in the assessments of the CARA project. This level of AU probability falls in the lowest 15 percent of all of the AUs evaluated in the CARA project. Because the 5.6 percent probability for the presence of at least one accumulation of the minimum size in the province is below the 10 percent threshold established for CARA assessments, this AU was not quantitatively assessed. Accordingly, estimations of the sizes and numbers of undiscovered accumulations, the petroleum composition, and other properties was not undertaken for the Jan Mayen Microcontinent.

\section{Conclusions}

The Jan Mayen Microcontinent is an isolated, mostly submarine, fragment of continental crust north of Iceland that was rifted away from the eastern margin of Greenland during formation of the North Atlantic Ocean in the Oligocene and Miocene. Although poorly known, its prerift stratigraphy and structural geology is thought to be similar to those of the highly prospective Norwegian, North Sea, and Greenland continental margins. The prospectivity of the Microcontinent is likely diminished, however, by Neogene extensional deformation, basaltic magmatism, and exhumation. Evaluation of the Jan Mayen Microcontinent AU by the CARA assessment team resulted in an overall probability of 5.6 percent for an accumulation of minimum size (50 MMBOE recoverable). This level of probability is in the lowest 15 percent of all of the AUs evaluated in the Arctic and is less than the 10 percent minimum necessary for a full quantitative assessment of the AU.

\section{Acknowledgments}

We thank CARA team members Kenneth J. Bird, Ronald R. Charpentier, Donald L. Gautier, David W. Houseknecht, Timothy R. Klett, Christopher J. Schenk and Marilyn E. Tennyson for their insightful advice and many very helpful contributions to our assessment of the Jan Mayen Microcontinent. Bird and Tennyson also reviewed the manuscript and provided many valuable comments and suggestions that greatly benefited the report.

\section{References Cited}

Allen, P.A., and Allen, J.R., 2005, Basin analysis, principals and applications: Oxford, U.K., Backwell Publishing, 549 p.

Baird, R.A., 1986, Maturation and source rock evaluation of Kimmeridge Clay, Norwegian North Sea: American Association of Petroleum Geologists Bulletin, v. 70, p. 1-11.

Barnard, P.C., and Bastow, M.A., 1991, Hydrocarbon generation, migration, alteration, and mixing in the central and northern North Seas, in England, W.A., and Fleet, A.J., eds., Petroleum migration: Geological Society of London, Special Publication, v. 59, p. 167-190.

Barrett, P., 2003, Paleoclimatology—Cooling a continent: Nature, v. 421, p. 221-223.

Bird, K.J., Charpentier, R.R., Gautier, D.L., Houseknecht, D.W., Klett, T.R., Pitman, J.K., Moore, T.E., Schenk, C.J., Tennyson, M.E., and Wandrey, C.R., 2008, Circum-Arctic Resource Appraisal-Estimates of undiscovered oil and gas north of the Arctic Circle: U.S. Geological Survey Fact Sheet 2008-3049, 4 p., accessed December 5, 2011, at http://pubs.usgs.gov/fs/2008/3049/.

Bird, K.J., and Houseknecht, D.W., 2011, Geology and petroleum potential of Arctic Alaska, in Spencer, A.M., Embry, A.F., Gautier, D.L., Stoupakova, A.V., and Sørensen, K., eds., Arctic petroleum geology: Geological Society of London, Memoir 35, p. 485-499. 
Charpentier, R.R., 2017, Methodology for assessment of undiscovered oil and gas resources for the 2008 CircumArctic Resource Appraisal, chap. B of Moore, T.E., and Gautier, D.L., eds., The Circum-Arctic Resource Appraisal: U.S. Geological Survey Professional Paper 1824, https:// doi.org/10.3133/pp1824B.

Charpentier, R.R., and Gautier, D.L., 2011, U.S. Geological Survey Circum-Arctic Resource Appraisal (CARA) - Introduction and summary of organization and methods, in Spencer, A.M., Embry, A.F., Gautier, D.L., Stoupakova, A.V., and Sørensen, K., eds., Arctic petroleum geology: Geological Society of London, Memoir 35, p. 145-150.

Christiansen, F.G., Dam, G., Piasecki, S., and Stemmerik, L., 1992, A review of Upper Paleozoic and Mesozoic source rocks from onshore East Greenland, in Spencer, A.M., ed., Generation, accumulation and production of Europe's hydrocarbons II: Special Publication of the European Association of Petroleum Geoscientists, no. 2, p.151-161.

Christiansen, F.G., Larsen, H.C., Marcussen, C., Piasecki, S., and Stemmerik, L., 1993, Late Paleozoic plays in East Greenland, in Parker, J.R., ed., Petroleum geology of northwest Europe-Proceedings of the 4th Conference: Geological Society of London, p. 657-666.

Copestake, P., Sims, A.P., Crittenden, S., Hamar, G.P., Ineson, J.R., Rose, P.T., and Tringham, M.E., 2003, Lower Cretaceous, chap. 12 in Evans, D., Graham, C., Armour, A., and Bathurst, P., eds., The millennium atlas-Petroleum geology of the central and northern North Sea: Geological Society of London, p. 191-211.

Coward, M.P., Dewey, J.F., Hempton, M., and Holroyd, J., 2003, Tectonic evolution, chap. 2 in Evans, D., Graham, C., Armour, A., and Bathurst, P., eds., The millennium atlasPetroleum geology of the central and northern North Sea: Geological Society of London, p. 17-33.

Doré, A.G., 1991, The structural foundation and evolution of Mesozoic seaways between Europe and the Arctic: Palaeogeography, Palaeoclimatology, Palaeoecology, v. 87, p. 441-492.

Eldholm, O., and Grue, K., 1994, North Atlantic volcanic margins-Dimensions and production rates: Journal of Geophysical Research, v. 99, p. 2955-2968.

Erratt, D., Thomas, G.M., Hartley, N.R., Musum, R., Hicholson, P.H., and Spisto, Y., 2010, North Sea hydrocarbon systems - Some aspects of our evolving insights into a classic hydrocarbon province, in Vining, B.A., and Pickering, S.C., eds., Petroleum geology-From mature basins to new frontiers-Proceedings of the 7th petroleum geology conference: Geological Society of London, p. 37-56.

Foulger, G.R., 2006, Older crust underlies Iceland: Geophysical Journal International, v. 165, p. 672-676.
Foulger, G.R., Natland, J.H., and Anderson, D.L. 2005, A source for Icelandic magmas in remelted Iapetus crust: Journal of Volcanology and Geothermal Research, v. 141, p. 23-44.

Frakes, L.A., Francis, J.E., and Syktus, J.I., 1992, Climate modes of the Phanerozoic - the history of the Earth's climate over the past 600 million years: Cambridge, U.K., Cambridge University Press, 274 p.

Fraser, S.I., Robinson, A.M., Johnson, H.D., Underhill, J.R., Kadolsky, D.G.A., Connell, R., Hohannessen, P., and Ravnås, R., 2003, Upper Jurassic, chap. 11 in Evans, D., Graham, C., Armour, A., and Bathurst, P., eds., The millennium atlas-Petroleum geology of the central and northern North Sea: London, Geological Society of London, p. 157-189.

Gaina, C., Gernigon, L., and Ball, P., 2009, Palaeocene-Recent plate boundaries in the NE Atlantic and the formation of the Jan Mayen microcontinent: Journal of the Geological Society of London, v. 166, p. 601-616.

Gautier, D.L., Bird, K.J., Charpentier, R.R., Grantz, A., Houseknecht, D.W., Klett, T.R., Moore, T.E., Pitman, J.K., Schenk, C.J., Schuenemeyer, J.H., Sørensen, K., Tennyson, M.E., Valin, Z.C., and Wandrey, C.J., 2009, Assessment of undiscovered oil and gas in the Arctic: Science, v. 324, p. 1175-1179.

Gautier, D.L., Bird, K.J., Charpentier, R.R., Grantz, A., Houseknecht, D.W., Klett, T.R., Moore, T.E., Pitman, J.K., Schenk, C.J., Schuenemeyer, J.H., Sørensen, K., Tennyson, M.E., Valin, Z.C., and Wandrey, C.J., 2011a, Oil and gas resource potential north of the Arctic Circle, in Spencer, A.M., Embry, A.F., Gautier, D.L., Stoupakova, A.V., and Sørensen, K., eds., Arctic petroleum geology: Geological Society of London Memoir 35, p. 151-161.

Gautier, D.L., Stemmerik, L., Christiansen, F.G., Sorensen, K., Bidstrup, T., Bojesen-Koefoed, J.A., Bird, K.J., Charpentier, R.R., Houseknecht, D.W., Klett, T.R., Schenk, C.J., and Tennyson, M.E., 2011b, Assessment of northeast Greenland-Prototype for development of Circum-Arctic Resource Appraisal methodology, in Spencer, A.M., Embry, A.F., Gautier, D.L., Stoupakova, A.V., and Sørensen, K., eds., Arctic petroleum geology: Geological Society of London Memoir 35, p. 663-672.

Golonka, J., and Kiessling, W., 2002, Phanerozoic time scale and definition of time slices, in Kiessling, W., Flügel, E., and Golonka, J., eds., Phanerozoic reef patterns: Society of Economic Paleontologists and Mineralogists Special Publication 72, p. 11-20. 
Gradstein, F.M., Ogg, J.G., and Smith, A.G., Agterberg, F.P., Bleeker, W., Cooper, R.A., Davydov, V., Gibbard, P., Hinnov, L.A., House, M.R., Lourens, L., Luterbacher, H.P., McArthur, J., Melchin, M.J., Robb, L.J., Shergold, J., Villeneuve, M., Wardlaw, B.R., Ali, J., Brinkhuis, H., Hilgen, F.J., Hooker, J., Howarth, R.J., Knoll, A.H., Laskar, J., Monechi, S., Plumb, K.A., Powell, J., Raffi, I., Röhl, U., Sadler, P., Sanfilippo, A., Schmitz, B., Shackleton, N.J., Shields, G.A., Strauss, H., Van Dam, J., van Kolfschoten, T., Veizer, J., and Wilson, D., 2004, A geologic time scale: Cambridge, U.K., Cambridge University Press, 589 p.

Grantz, A., Scott, R.A., Drachev, S.S., and Moore, T.E., 2010, Map showing sedimentary successions of the Arctic Region, $58^{\circ}-64^{\circ}$ to $90^{\circ} \mathrm{N}$, that may be prospective for hydrocarbons: American Association of Petroleum Geologists GIS OpenFile, 2 plates, scale 1:6,760,000, and explanatory pamphlet, 78 p., last accessed October 9, 2015, at http://datapages. com/gis-map-publishing-program/gis-open-files/geographic/ sedimentary-successions-of-the-arctic-region-by-grantz-etal-2010.

Grantz, A., Scott, R.A., Drachev, S.S., Moore, T.E., and Valin, Z.C., 2011, Sedimentary successions of the Arctic region $\left(65^{\circ}-90^{\circ} \mathrm{N}\right)$ that may be prospective for hydrocarbons in Spencer, A.M., Embry, A.F., Gautier, D.L., Stoupakova, A.V., and Sørensen, K., eds., Arctic petroleum geology: Geological Society of London Memoir 35, p. 17-37.

Gudlaugsson, S.T., Gunnarsson, K., Sand, M., Skogseid, J., 1988, Tectonic and volcanic events at the Jan Mayen Ridge microcontinent, in Morton, A.C., and Parson, L.M., eds., Early Tertiary volcanism and the opening of the NE Atlantic: Geological Society of London Special Publication 39, p. 85-93.

Hamann, N.E., Whittaker, R.C., and Stemmerik, L., 2005, Geological development of the northeast Greenland shelf, in Doré, A.G., and Vining, B.A., eds., Petroleum geologyNorth-west Europe and global perspectives-Proceedings of the 6th petroleum geology conference: Geological Society of London, p. 887-902.

Hansen, K., Bergman, S.C., and Henk, B., 2001, The Jameson Land basin, east Greenland-A fission track study of the tectonic and thermal evolution in the Cenozoic North Atlantic spreading regime: Tectonophysics, v. 331, p. 307-339.

Hardenbol, J., Thierrt, J., Farley, M.B., Jacquin, T., de Graciansky, P.-C., and Vail, P.R., 1998, Mesozoic and Cenozoic sequence chronostratigraphic framework for European basins, in de Graciansky, P.-C., Hardenbol, J., Jacquin, T., and Vail, P.R., eds., Mesozoic and Cenozoic sequence stratigraphy of European basins: Society of Economic Paleontologists and Mineralogists Special Publication 60, p. 3-13.
Henriksen, N., Higgins, A.K., Kalsbeek, F., and Pulvertaft, T.C.R, 2000, Greenland from Archaean to Quaternarydescriptive text to the Geological map of Greenland 1:2,500,000: Geology of Greenland Survey Bulletin 185, p. 93

Houseknecht, D.W., and Bird, K.J., 2011, Geology and petroleum potential of the rifted margins of the Canada Basin, in Spencer, A.M., Embry, A.F., Gautier, D.L., Stoupakova, A.V., and Sørensen, K., eds., Arctic petroleum geology: Geological Society of London Memoir 35, p. 509-526.

Houseknecht, D.W., Bird, K.J., and Garrity, C.P., 2012a, Assessment of undiscovered petroleum resources of the Amerasia Basin Petroleum Province: U.S. Geological Survey Scientific Investigations Report 2012-5146, 35p.

Houseknecht, D.W., Bird, K.J., and Garrity, C.P., 2012b, Assessment of undiscovered petroleum resources of the Arctic Alaska Petroleum Province: U.S. Geological Survey Scientific Investigations Report 2012-5147, 26 p.

Husmo, T., Hamar, G.P., Høiland, O., Johannessen, R.P., Rømuld, A., Spencer, A.M., and Titterton, R., 2003, Lower and Middle Jurassic, in Evans, D., Graham, C., Armour, A., and Bathurst, P., eds., The millennium atlas-Petroleum geology of the central and northern North Sea: Geological Society of London, p. 129-155.

Iceland GeoSurvey, 2008, Geology and hydrocarbon potential of the northern Dreki Area, Icelandic continental shelf: Orkustofnun, Ministry of Industry, Iceland National Energy Authority, presentation downloaded on November 16, 2010, from http://eng.idnadarraduneyti.is/media/frettir/Hydrocarbon potential_in the Dreki area_pdf.

Integrated Exploration Systems [Schlumberger Limited], 2008, PetroMod 1D, ver. 10 software: Houston, Texas, Schlumberger [previously IES, Ritterstrasse 23, D-52072, Aachen, Germany, www.ies.de].

Jakobsson, M., Macnab, R., Cherkis, N., and Schenke, H., 2004, International bathymetric chart of the Arctic Ocean [IBCAO]: National Geophysical Data Center, Research Publication RP-2, 1 plate, scale 1:6,000,000.

Kimbell, G.S., Ritchie, J.D., Johnson, H., and Gatliff, R.W., 2005, Controls on the structure and evolution of the NE Atlantic margin revealed by regional potential field imaging and 3D modeling, in Doré, A.G., and Vining, B.A., eds., Petroleum Geology - Northwest Europe and global perspectives-Proceedings of the 6th petroleum geology conference: Geological Society of London, p. 933-945.

Klett, T.R., and Pitman, J.K., 2011, Geology and petroleum potential of the East Barents Sea basins and Admiralty arch, in Spencer, A.M., Embry, A.F., Gautier, D.L., Stoupakova, A.V., and Sørensen, K., eds., Arctic petroleum geology: Geological Society of London Memoir 35, p. 295-310. 
Klett, T.R., Wandrey, C.J., and Pitman, J.K., 2011, Geology and petroleum potential of the north and east margins of the Siberian craton, in Spencer, A.M., Embry, A.F., Gautier, D.L., Stoupakova, A.V., and Sørensen, K., eds., Arctic petroleum geology: Geological Society of London Memoir 35, p. 413-431.

Kodaira, S., Mjelde, R., Shimamura, H., Gunnarsson, K., Shiobara, H., and Shimamura, H., 1998, Structure of the Jan Mayen microcontinent and implications for its evolution: Geophysical Journal International, v. 132, p. 383-400.

Kubala M., Bastow, M., Thompson, S., Scotchman, I., and Oygard, K., 2003, Geothermal regime, petroleum generation and migration, chap. 17 in Evans, D., Graham, C., Armour, A., and Bathurst, P., eds., The millennium atlasPetroleum geology of the central and northern North Sea: Geological Society of London, p. 289-315.

Kuvaas, B., and Kodaira, S., 1997, The formation of the Jan Mayen microcontinent-The missing piece in the continental puzzle between the More-Voring Basins and East Greenland: First Break, v. 15, p. 239-247.

Larsen, M., Hamberg, L., Olaussen, S., Nørgaard-Pedersen, N., and Stemmerik, L., 1999, Basin evolution in southern East Greenland-An outcrop analog for CretaceousPaleogene basins on the North Atlantic volcanic margins: American Association of Petroleum Geologists Bulletin, v. 83, no. 8, p. 1236-1261.

Lawver, L.A., and Müller, D.R., 1994, Iceland 'hotspot' track: Geology, v. 22, p. 311-314.

Laxon, S.W., and McAdoo, D.C., 1997, Polar marine gravity fields from ERS-1: European Space Agency, Proceedings of the third ERS symposium on space at the service of our environment, v. III, p. 1547-1552, available at https://earth. esa.int/documents/10174/1598482/GEN73.pdf.

Lundin, E., and Doré, A.G., 2002, Mid-Cenozoic post-breakup deformation in the 'passive' margins bordering the Norwegian - Greenland Sea: Marine and Petroleum Geology, v. 19, p. 79-93.

Lundin, E., and Doré, A.G., 2005, NE Atlantic breakup-A re-examination of the Iceland mantle plume model and the Atlantic-Arctic linkage, in Doré, A.G., and Vining, B.A., eds., Petroleum geology — Northwest Europe and global perspectives-Proceedings of the 6th petroleum geology conference: Geological Society of London, p. 739-754.

Mathiesen, A., Bidstrup, T., Christiansen, F.G., 2000, Denudation and uplift history of the Jameson Land basin, East Greenland-Constrained from maturity and apatite fission track data: Global and Planetary Change, v. 24, p. 275-301.
Mathiesen, A., Christiansen, F.G., Bidstrup, T., Marcussen, C., Dam, G., Piasecki, S., and Stemmerik, L., 1995, Modeling of hydrocarbon generation in the Jameson Land Basin, East Greenland: First Break, v. 13, p. 329-341.

Mjelde, R., Breivik, A.J., Raum, T., Mittelstaedt, E., Ito, G., and Faleide, J.I., 2008, Magmatic and tectonic evolution of the North Atlantic: Journal of the Geological Society of London, v. 165, p. 31-42.

Moore, T.E., Grantz, A. Pitman, J.K., and Brown, P.J., 2011, A first look at the petroleum geology of the Lomonosov Ridge microcontinent, Arctic Ocean, in Spencer, A.M., Embry, A.F., Gautier, D.L., Stoupakova, A.V., and Sørensen, K., eds., Arctic petroleum geology: Geological Society of London Memoir 35, p. 751-769.

Moore, T.E., and Pitman, J.K., 2011, Geology and petroleum potential of the Eurasia Basin in Spencer, A.M., Embry, A.F., Gautier, D.L., Stoupakova, A.V., and Sørensen, K., eds., Arctic petroleum geology: Geological Society of London Memoir 35, p. 731-750.

Mosar, J., Lewis, G., and Torsvik, T.H., 2002, North Atlantic sea-floor spreading rates-Implications for the Tertiary development of inversion structures of the NorwegianGreenland Sea: Journal of the Geological Society of London, v. 159 , p. 503-515.

Müller, R.D., Gaina, C., Roest, W.R., and Hansen, D.L., 2001, A recipe for microcontinent formation: Geology, v. 29, p. 203-206.

Myhre, A.M., Eldholm, O., and Sundvor, E., 1984, The Jan Mayen Ridge_-Present status: Polar Research, v. 2, p. 47-59.

Nilsen, T.H., and Kerr, D.R., 1978, Turbidites, redbeds, sedimentary structures, and trace fossils observed in DSDP leg 38 cores and the sedimentary history of the Norwegian-Greenland: Initial Reports of the Deep Sea Drilling Project, v. 38 supplement, p. 259-288, doi:10.2973/dsdp. proc.38394041s.118.1978.

Nøttvedt, A,. Johannessen, E.P., and Surlyk, F., 2008, The Mesozoic of western Scandinavia and East Greenland: Episodes, v. 31, p. 59-65.

Nunns, A.G., 1983, The structure and evolution of the Jan Mayen Ridge and surrounding regions, in Watkins, J.S., and Drake, C.L., eds., Continental margin geology: American Association of Petroleum Geologists Memoir v. 34, p. 193-208.

Oakey, G.N., Scott, R.A., Jackson, H.R., and Macnab, R., 1999, Circum-Arctic magnetic map with tectonic overlay, polar stereographic projections, scale 1:6,000,000 at $75^{\circ} \mathrm{N}$ Latitude: Geological Survey of Canada Open File 3691. 
Paquette, J., Sigmarsson, O., Tiepolo, M., 2006, Continental basement under Iceland revealed by old zircons [abs.]: Eos [Transactions of the American Geophysical Union], Fall Meeting Supplement, v. 87, p. 52.

Price, S.P., and Whitham, A.G., 1997, Exhumed hydrocarbon traps in East Greenland-Analogs for the Lower-Middle Jurassic play of northwest Europe: American Association of Petroleum Geologists Bulletin, v. 81, p. 196-221.

Requejo, A.G., Hollywood, J., and Halpern, H.I., 1989, Recognition and source correlation of migrated hydrocarbons in Upper Jurassic Hareelv Formation, Jameson Land, East Greenland: American Association of Petroleum Geologists Bulletin, v. 73, p. 1065-1088.

Schenk, C.J., 2011a, Geology and petroleum potential of the Timan-Pechora Basin province, Russia, in Spencer, A.M., Embry, A.F., Gautier, D.L., Stoupakova, A.V., and Sørensen, K., eds., Arctic petroleum geology: Geological Society of London Memoir 35, p. 283-294.

Schenk, C.J., 2011b, Geology and petroleum potential of the West Greenland-East Canada province, in Spencer, A.M., Embry, A.F., Gautier, D.L., Stoupakova, A.V., and Sørensen, K., eds., Arctic petroleum geology: Geological Society of London Memoir 35, p. 627-645.

Scott, R., Ramsey, L.A., Jones, S.M., Sinclair, S., and Pickles, C.S., 2005, Development of the Jan Mayen microcontinent by linked propagation and retreat of spreading ridges, in Wandas, B.T.G., Nystuen, J.P., Eide, E., and Gradstein, F., eds., Onshore-offshore relationships on the North Atlantic Margin: Norwegian Petroleum Society, p. 69-82.

Sigmond, E.M.O., 2002, Geological map, land and sea areas of Northern Europe: Geological Survey of Norway, scale $1: 4,000,000$.

Sørensen, K., Gautier, D., Pitman, J., Jackson, H.R., and DahlJensen, T., 2011, Geology and petroleum potential of the Lincoln Sea Basin, offshore North Greenland, in Spencer, A.M., Embry, A.F., Gautier, D.L., Stoupakova, A.V., and Sørensen, K., eds., Arctic petroleum geology: Geological Society of London Memoir 35, p. 673-684.

Stemmerik, L., 2000, Late Palaeozoic evolution of the North Atlantic margin of Pangea: Palaeogeography, Palaeoclimatology, Palaeoecology, v. 161, p. 95-126.

Stemmerik, L., Christiansen, F.G., Piasecki, S., Jordt, B., Marcussen, C., and Nøhr-Hansen, 1992, Depositional history and petroleum geology of the Carboniferous to Cretaceous sediments in the northern part of East Greenland, in Vorren, T.O., Bergsager, O.A., Dahl-Stamnes, ø.A, Holter, E., Johansen, B., Lie, E., and Lnd, T.B, Arctic Geology and petroleum potential: Norwegian Petroleum Society Special Publication 2, p. 67-87.
Swiecicki, T., Gibbs, P.B., Farrow, G.E., and Coward, M.P., 1998, A tectonostratigraphic framework for the mid-Norway region: Marine and Petroleum Geology, v. 15, p. 245-276.

Talwani, M., and Eldholm, O., 1977, Evolution of the Norwegian-Greenland Sea: Geological Society of America Bulletin, v. 88, p. 969-999.

Talwani, M., Udintsev, G., Bjorklund, K., Caston, V.N.D., Faas, R.W., Kharin, G.N., Morris, D.A., Muller, C., Nilsen, T.H., van Hinte, J., Warnke, D.A., and White, S.M., 1976, Sites 346, 347, 348, 349 and 350: Initial Reports of the Deep Sea Drilling Project, v. 38, p 521-682.

Thomas B.M., Moller-Pedersen, P., Whitaker, M.F., and Shaw, N.D., 1985, Organic facies and hydrocarbon distributions in the Norwegian North Sea, in Thomas, B.M., Dore, A.G., Eggen, S.S., Horne, P.C., and Larsen, R.M., eds., Petroleum geochemistry in exploration of the Norwegian shelf: Norwegian Petroleum Society, p. 3-26.

Tuitt A., Underhill, J.R., Ritchie, J.D., Johnson, H., and Hitchen, K., 2010, Timing, controls and consequences of compression in the Rockall-Faroe area of the NE Atlantic margin, in Vining, B.A., and Pickering, S.C., eds., Petroleum geology - From mature basins to new frontiers-Proceedings of the 7th petroleum geology conference, v. 2: Geological Society of London, p. 963-978.

Ulmishek, G.F., and Klemme, H.D., 1990, Depositional controls, distribution, and effectiveness of world's petroleum source rocks: U.S. Geological Survey Bulletin B-1931, 59 p.

Verhoef, J., Roest, W.R., Macnab, R., and Arkani-Hamed, J., 1996, Magnetic anomalies of the Arctic and North Atlantic oceans and adjacent land areas: Geological Survey of Canada Open File 3125a, 1 sheet.

Zanella, E., and Coward, M.P., 2003, Structural framework, chap. 3 in Evans, D., Graham, C., Armour, A., and Bathurst, P., eds., The millennium atlas-Petroleum geology of the central and northern North Sea: Geological Society of London, p. 45-59. 


\section{Appendix}

Appendix is available online only, and may be accessed at https://oi.org/10.3133/pp1824L

Appendix 1. Input Data for the Jan Mayen Microcontinent Assessment Unit 


\section{兽}

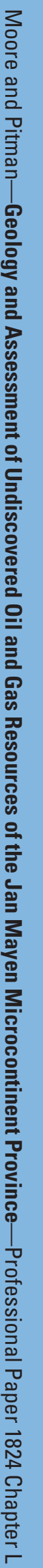

